1978

\title{
An Archaeological Assessment of The Dolores Aldrete House Property San Antonio, Texas
}

Daniel E. Fox

Fred Valdez Jr.

Department of Anthropology, The University of Texas at Austin

Lynn Osborne Bobbitt

Follow this and additional works at: https://scholarworks.sfasu.edu/ita

Part of the American Material Culture Commons, Archaeological Anthropology Commons, Environmental Studies Commons, Other American Studies Commons, Other Arts and Humanities Commons, Other History of Art, Architecture, and Archaeology Commons, and the United States History Commons

Tell us how this article helped you.

This Article is brought to you for free and open access by the Center for Regional Heritage Research at SFA ScholarWorks. It has been accepted for inclusion in Index of Texas Archaeology: Open Access Gray Literature from the Lone Star State by an authorized editor of SFA ScholarWorks. For more information, please contact cdsscholarworks@sfasu.edu. 


\section{An Archaeological Assessment of The Dolores Aldrete House Property San}

Antonio, Texas

\section{Creative Commons License}

\section{(c) (1) \&}

This work is licensed under a Creative Commons Attribution-NonCommercial 4.0 International License 


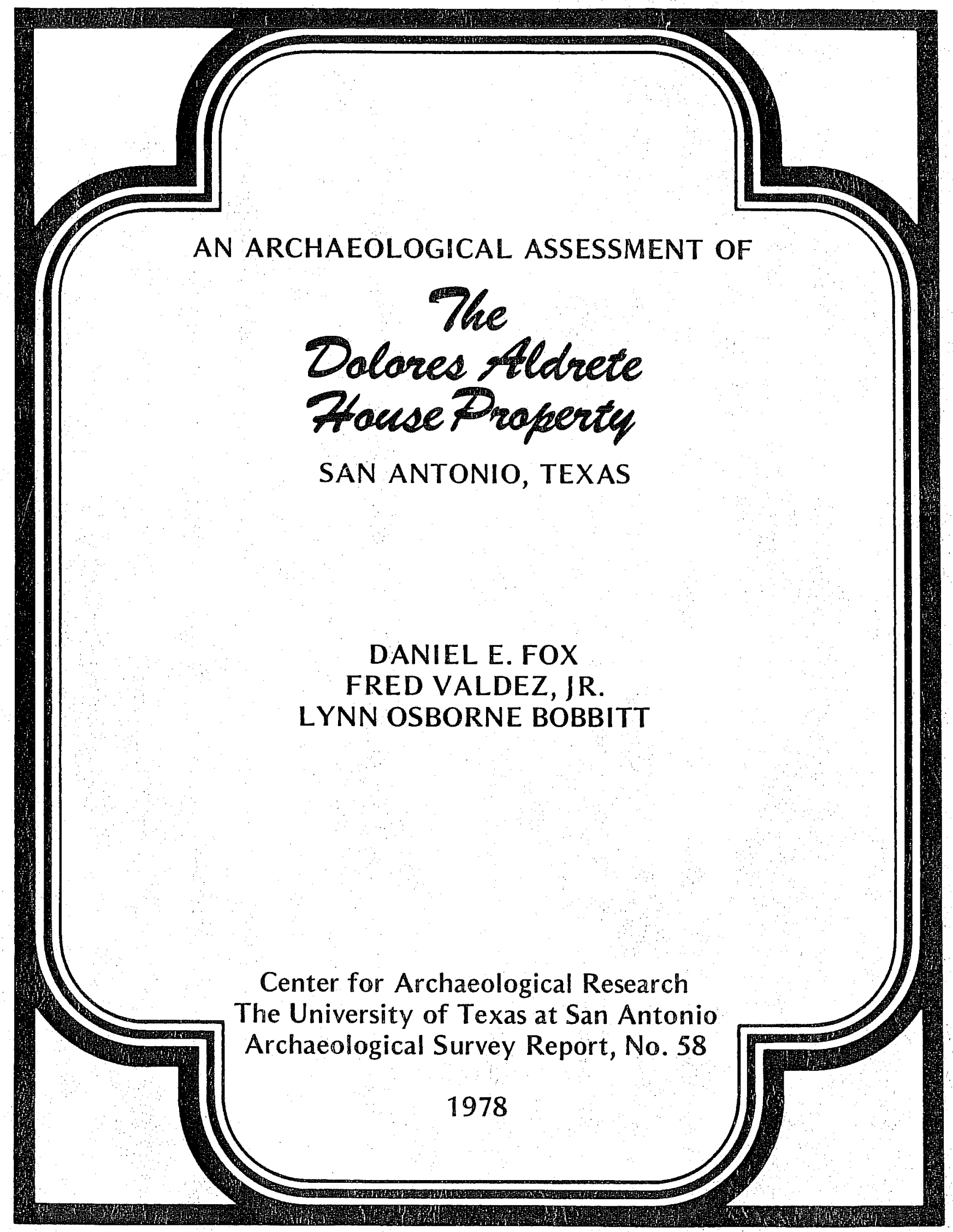




\title{
AN ARCHAEOLOGICAL ASSESSMENT \\ OF THE DOLORES ALDRETE HOUSE PROPERTY \\ SAN ANTONIO, TEXAS
}

\author{
Daniel E. Fox \\ Fred Valdez, Jr. \\ Lynn Osborne Bobbitt
}

Center for Archaeological Research The University of Texas at San Antonio Archaeological Survey Report, No. 58

1978 
List of figures.................. . . i i List of Tables .......................... ii Acknowledgments.................. iv

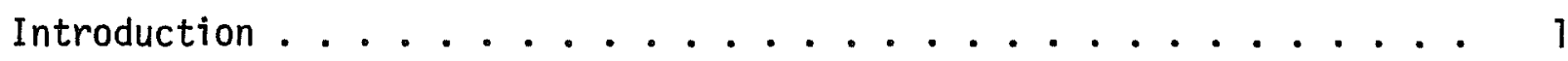
Archaeological Background. .................. 1 Site Description................... 3 Methodology...................... 9 Structural Features................. 13 Cultural stratigraphy. . . . . . . . . . . . 15 Cultural Materials .................. 17 Interpretations and Conclusions. .............. 26 Recommendations................... 26 26 References cited................... 31 


\section{LIST OF FIGURES}

Figure

Page

1. The La Villita Neighborhood, Downtown San Antonio, Texas. . . . 2

2. Plan of Dolores Aldrete House Property. . . . . . . . . . 4

3. Front Elevations of Structures.............. 5

4. Test Pit 1................... 10

5. Test Pits 2 and $3 \ldots \ldots \ldots \ldots$

6. Test Pits 4 and $5 \ldots \ldots 12$

7. Profiles of Test Pits $1,2,3$ and $4 \ldots 14$

8. Profile of Test Pit 5 ............. 16

9. Selected Artifacts, Construction Materials. . . . . . . . . 18

10. Selected Artifacts, Household and Personal Items. . . . . . . 19

11. Selected Artifacts, Kitchen Materials (Pottery) . . . . . . 20

12. Selected Artifacts, Kitchen Materials (Glass Bottles) ...... 21 


\section{LIST OF TABLES}

Table

Page

1. Dolores Aldrete House. Construction Materials and Proveniences . . . 22

2. Dolores Aldrete House. Household, Personal Items and

Proveniences. . . . . . . . . . . . . . . . . 23

3. Dolores Aldrete House. Kitchen Artifacts and Proveniences . . . . . 24

4. Dolores Aldrete House. Miscellaneous Cultural Materials and Proveniences ................. 25

5. Dolores Aldrete House. Chronological Association of Selected Artifact Categories . . . . . . . . . . . . . 27

6. Dolores Aldrete House. Chronological Association of Cultural Deposits. . . . . . . . . . . . . . . . 28

7. Dolores Aldrete House. Chronology of Events. . . . . . . . . . 29 


\section{ACKNOWLEDGMENTS}

The accomplishment of this preliminary archaeological investigation would not have been as successful and enjoyable without the cooperation of a variety of individuals. Carol Lee Klose, Gary Mark Klose, Randall Mark Klose, Dolores Klose and friends supported the study and made the field work a pleasant and worthwhile exercise. Professional restoration planner Killis Almond and carpenter Woody Wilhelm made their expertise available throughout the field work. Lynn Osborne Bobbitt contributed the preliminary historic background presented in this report and offered her help during the write-up phase of the project. Professional photographer Vicki Holloway provided back-up documentation of the field work. Assistant State Archaeologist Alton K. Briggs offered his moral support and encouragement.

Greatly appreciated is the volunteer labor received from the UTSA Center for Archaeological Research, Anne Fox and Shirley Van der Veer, and from UTSA anthropology students Dianne Detrio, Betty Markey, Harold Prestridge and Sylvia Bento. Becky Halpern helped with the preliminary analys is of the sample of faunal remains. Jack Eaton, Assistant Director of the Center, initiated the project and provided general supervision. Editorial assistance in the preparation of the manuscript was provided by Thomas R. Hester, Director of the Center.

The patience and cooperation of the news media also is appreciated. 


\section{INTRODUCTION}

During March and April 1978, a preliminary archaeological investigation was conducted at the historic "Dolores Aldrete House," lots 7, 8 and 9 of block 155, fronting on East Nueva Street in downtown San Antonio, Texas. Under contract with the property owners, Carol Lee Klose, Gary Mark Klose and Randa11 Mark Klose, and the Center for Archaeological Research, two archaeologists from the Center investigated the age, nature of construction and condition of the depth and character of cultural deposits and evaluated the archaeological potential of the site.

Following is a report on the findings of this archaeological investigation, accompanied by a preliminary history of site occupation and recommendations for future management of the Dolores Aldrete House property as a cultural resource.

The field work was done by Daniel Fox, assisted by Fred Valdez, Jr., and aided by the volunteers already mentioned. All field work was conducted under the direction of Dr. Thomas R. Hester, Director, and Mr. Jack D. Eaton, Assistant Director, the Center for Archaeological Research.

\section{ARCHAEOLOGICAL BACKGROUND}

Unfortunately, little archaeological work has been done in downtown San Antonio (Fig. 1), and most of what has been done has been in the form of short-term salvage or preliminary investigations of monumental sites, such as the Alamo (Eaton n.d.a; Fox, Bass and Hester 1976), the San Fernando Cathedral (Eaton n.d.b; Fox, Scurlock and Clark 1977), and the Spanish Governor's Palace (Fox 1977). More limited study has been made of residential sites in the downtown area.

In 1966 Mardith K. Schuetz (1970), representing the Witte Memorial Museum, excavated a section of the Acequia Madre in the Hemisfair area. Later, Schuetz (n.d.) investigated a stone ruin, purported to be the remains of a Spanish cuartel. Located behind the German-English School (Fig. 1), this site yielded primarily late 19 th century cultural material.

In 1976 Paul Katz and Anne Fox, representing the Center for Archaeological Research, UTSA, investigated city blocks 1-5 and 901, the site of the proposed Plaza Nacional hotel (Fig. 1), and recovered evidence of mid-19th to mid-20th century residential occupation (field notes on file, CAR, UTSA). More recently, James Ivey has conducted an investigation of the Gresser House (Fig. 1), a 19th century residence in La Villita (Ivey 1978).

The research objectives of most of the previous archaeological work have been determined by the practical need for structural information, assessment of archaeological potential, and salvaging of material culture and data on archaeological features.

The present investigation of the Dolores Aldrete House property (Fig. 1) was oriented toward the accomplishment of similar objectives. Its primary purpose was to evaluate the archaeological potential of the site so that recommendations can be made for management of the property as an historic site. 


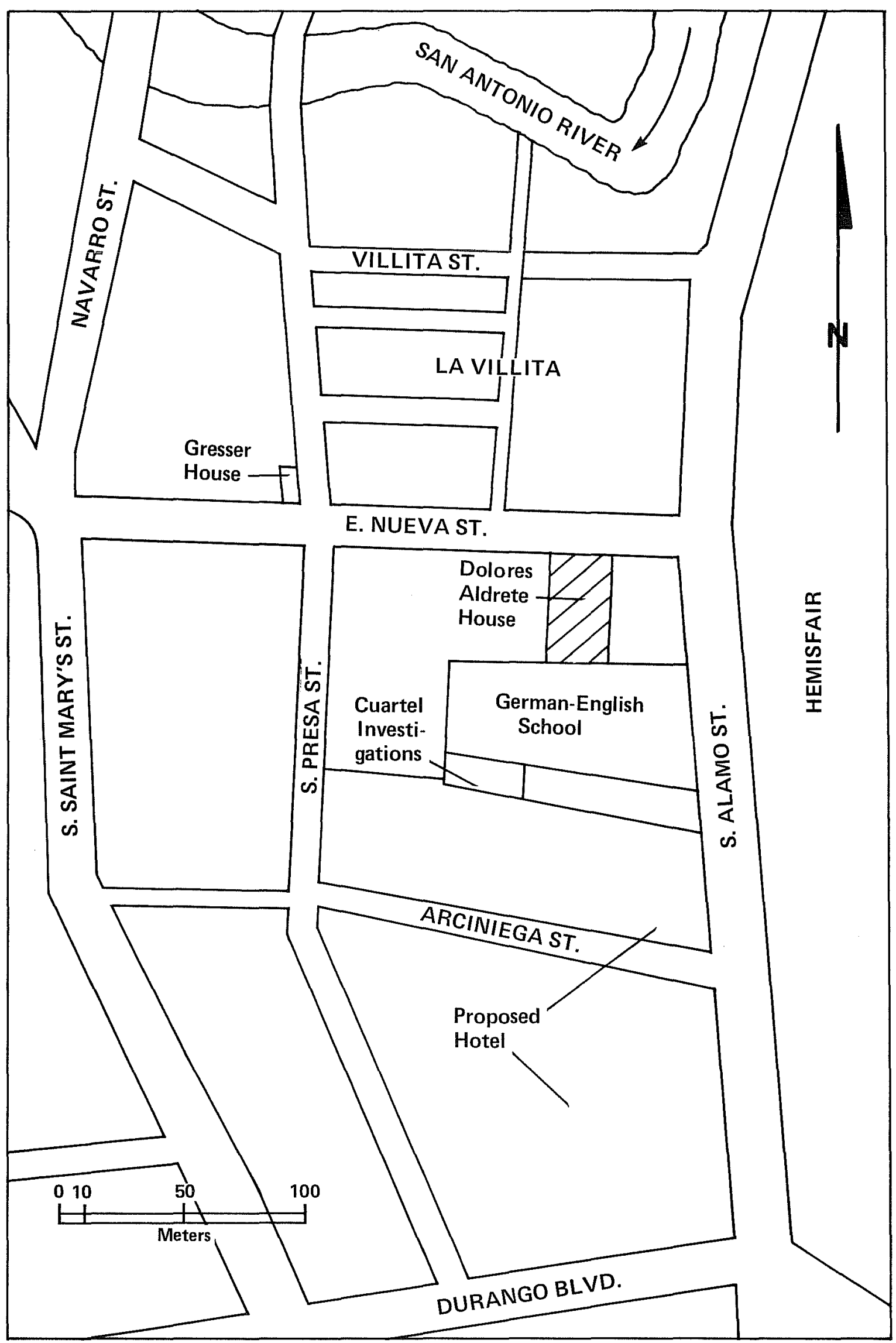

Figure 1. The La Villita Neighborhood, Downtown San Antonio, Texas. Location of Dolores Aldrete House is indicated. 


\section{SITE DESCRIPTION}

The Dolores Aldrete House property is comprised of 1ots 7, 8 and 9 of city block 1 and fronts on East Nueva Street (526 East Nueva) south of the La Villita complex in downtown San Antonio (Fig. 2). The property is surrounded by fences and walls which, along with various structures, form an enclosure or courtyard (Fig. 2).

The Caile House (Fig. 3,a), a mid-19th century two-room "caliche block" (or tufa limestone) structure with a more recent two-room brick and frame addition, is situated on the northern end of lots 7 and 8 . The jacal Dolores Aldrete House (also referred to as the "palisado house") is located on the southern end of lot 9 (Fig. 3,b). Late 19th and 20th century additions extend across the entire southern end of lots 7,8 and 9. The open area of the courtyard consists of a gravel driveway and parking area (1ots 7 and 8 ) and a grass-covered yard (1ot 9) landscaped with trees and shrubs.

As a unit, the property forms an oasis of greenery amidst the rapidly developing urban neighborhood of asphalt streets and parking lots, La Villita, Hemisfair Plaza, the Palacio del Rio Hotel and other cultural-geographic features (Fig. 1).

History of Site Occupation*

The following is a chain of title from 1818 to 1968 to the land on which the two historical structures stand. The references are recorded in the deed records of the Office of the Bexar County Clerk in the Bexar County Courthouse, San Antonio, Texas, unless otherwise noted.

1818 - Spanish Land Grant, February 3, 1818, Spanish Vol. 2, p. 119-120. Antonio Martinez, Governor of the Province of Texas to Dolores Aldrete. A solar consisting of 30 varas frontage and 50 varas depth. Block 155, Lots 7, 8 and 9.

1848 - Deed, January 7, 1848, Vo1. J1, p. 348. Maria Concepcion Gil to Adanto de la Zerda. Lot 7.

1848 - Deed, January 7, 1848, Vol. J1, p. 349. Adanto de la Zerda to Canuto Diaz. Lot 7.

1853 - Deed, December 23, 1853, Vol. L2, p. 13. Manuel Casillas to Mariano Casillas. Lots 8 and 9.

1854 - Deed, July 28, 1854, Vol. M1, p. 200. Mariano Casillas and wife to Juan Saucedo. Lots 8 and 9.

1857 - Deed, January 20, 1857, Vo1. 02, p. 340. Juan Saucedo and wife Teresa Flores to Robert Caile. Lot 8.

1857 - Deed, August 12, 1857, Vo1. R1, p. 24. Canuto Diaz and wife Margarita Zamora to Robert Caile. Lot 7. 


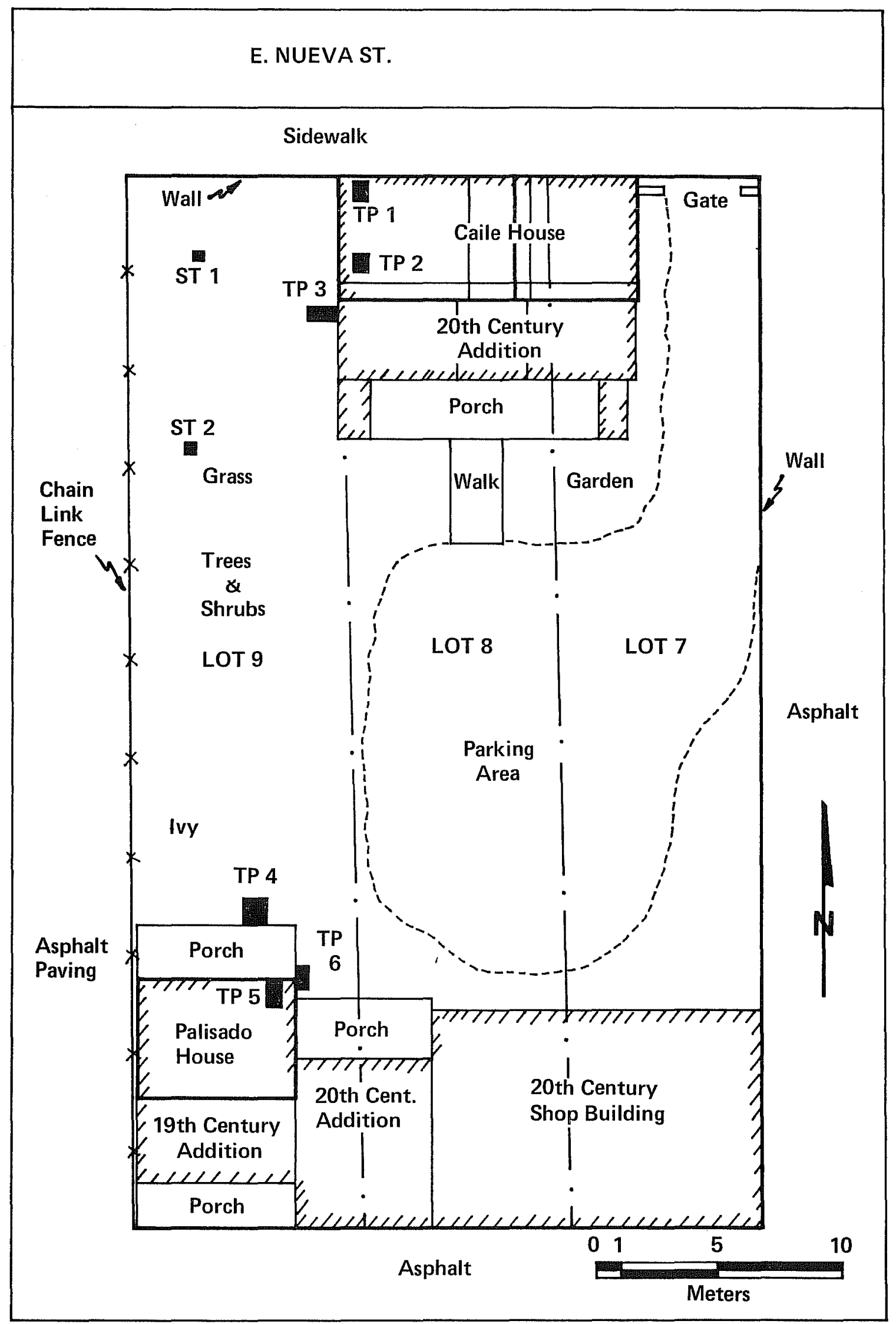

Figure 2. Plan of Dolores Aldrete House Property. 


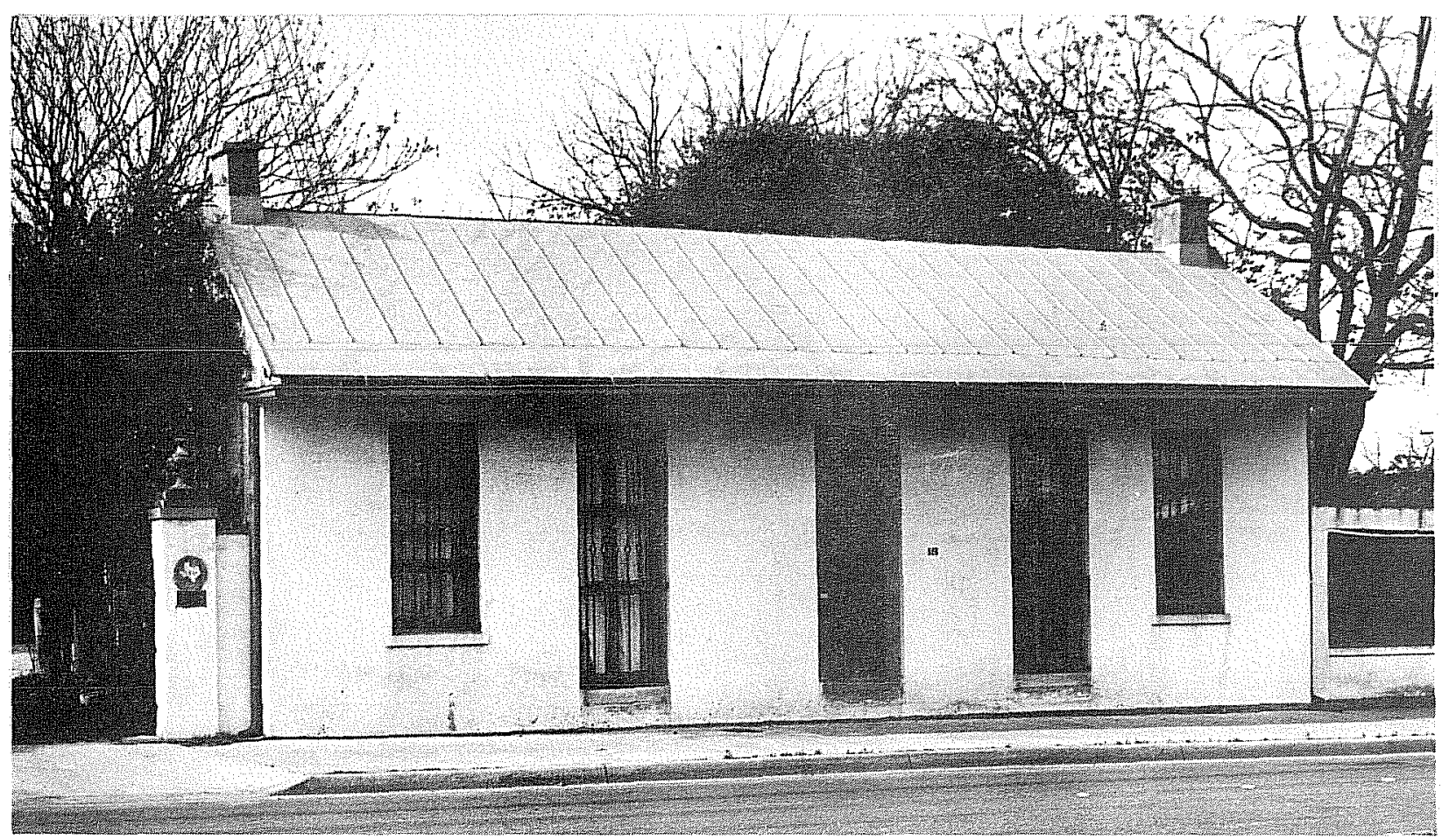

a

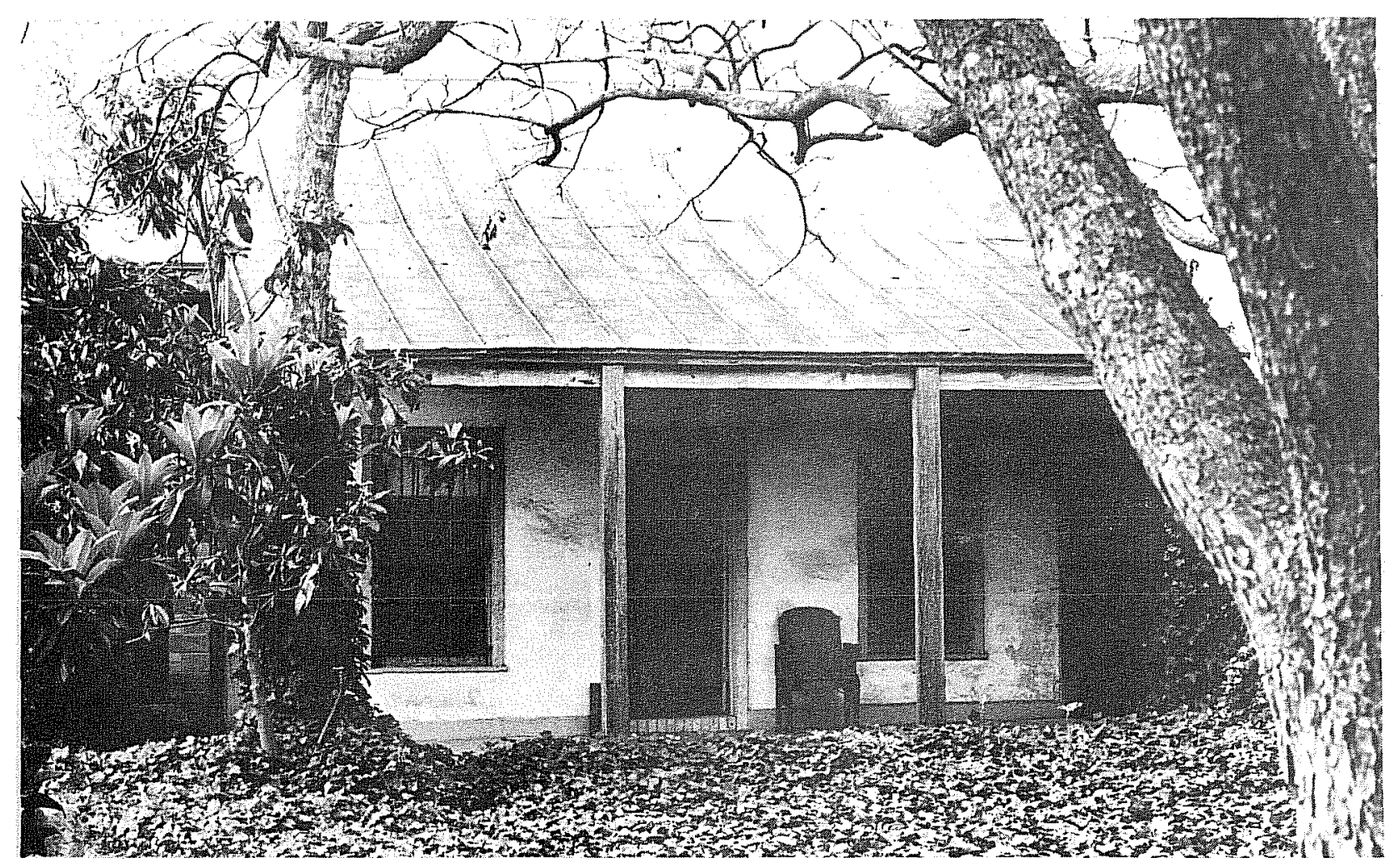

b

Figure 3. Front Elevations of Structures. a, 20th century facade of mid-19th century Caile House; b, Dolores Aldrete (Palisado) House. 
1859 - Deed, September 20, 1859, Vo1. R1, p. 215. Juan Saucedo and wife Teresa Flores to Santa Flores Gortares, wife of Miguel Gortares. Lot 9.

1871 - Deed, December 18, 1871, Vo1. W2, p. 200. Teresa Flores to Mariana Reidel, wife of Charles Reidel. Lot 9.

1881 - Deed, May 9, 1881, Vo1. 12, p. 242. Mariana Reidel and Charles Reidel to Henry Wincke. Lot 9 .

1885 - Deed, Apri1 24, 1885, Vo1. 42, p. 4. Henry Wincke to Jacob Hotz. Lot 9.

1893 - Tax Suit, November 10, 1893, File No. 1967, City of San Antonio vs.

Robert Caile. Office of Bexar County District Clerk. Lots 7 and 8.

1893 - Deed, December 12, 1893, Vo1. 123, p. 495. Mary Caile et al. to Lola

Caile. Lots 7 and 8 .

1894 - Deed, January 3, 1894, Vo1. 123, p. 498. Lola Caile to Jacob Hotz. Lots 7 and 8.

1927 - Deed, May 31, 1927, Vo1. 957, p. 513. Jacob Hotz to City of San Antonio. For $\$ 5,220.44$ agreed to sell portions of lots 7,8 and 9 , remove all buildings and secure the release of all tenants.

1928 - Certified copy of a City Ordinance, January 15, 1928, Vo1. 1063, p. 33. City of San Antonio to Uvalde Rock Asphalt Company to grade, pave, and construct or re-set curbs on E. Nueva Street from Garden Street (St. Mary's) to S. Alamo Street. Lots 7, 8 and 9.

1929 - Executor's Deed, January 22, 1929, Vol. 1083, p. 156. Estate of Jacob Hotz; Henry Rilling, Jr., Independent Executor to Alma C. Weber, wife of Frank $H$. Weber et al. Lots 7,8 and 9.

1944 - Deed, March 15, 1944, Vol. 20, p. 110. W. S. Appmann to Gonzalo Veiga. Lots 7,8 and 9 .

1966 - Lease agreement, September 7, 1966-January 11, 1968, Vol. 5891, p. 232. Gonzalo Veiga to Russe 11 M. Stanley and James W. Newton. Lots 7, 8 and 9.

1968 - Suit for Specific Performance, January 15, 1968, 45th District Court, No. 196708. James W. Newton and Russell Stanley vs. Gonzalo Veiga. Lots 7, 8 and 9 .

1968 - Notice of Lis Pendens, January 29, 1968, 45th District Court, No. 872350.

1968 - Deed of Trust, March 11, 1968, Vol. 5930, p. 420, Russel1 M. Stanley and James $W$. Newton to Travis Savings \& Loan. Lots 7, 8 and 9.

1968 - Deed, March 11, 1968, Vo1. 5943, p. 755. Gonzalo Veiga to Russell M. Stanley and James W. Newton. Lots 7,8 and 9. 
The site on which the two structures presently stand originally was a land grant received by Dolores Aldrete from the Spanish Government. In 1812 Dolores Aldrete appeared before the Spanish Governor of the Province of Texas, Manuel Saucedo, to petition for a solar of land to be granted to her in recognition of the service given by her deceased husband, Ygnacio Gil (Ignacio), in the Spanish army. She requested the land situated "to the rear of the quartel" and the Governor subsequently conveyed the land to her. She stated in the petition that she then built a "casa de madera" or a wooden house, most likely the palisado house situated on lot 9. Although Sra. Aldrete had obtained the right of possession of the land in 1812, she did not receive the deed to the property until she petitioned for the title in 1818. The property, having a frontage of thirty varas and a depth of fifty varas, was bounded on the north by the calle Real (Nueva Street), on the south by public lands, on the west by land of Jose Leal and on the east by land of Gregorio Arciniega.

The property was located in the barrio or district of the city known as La Villita. The land originally belonged to Mission San Antonio de Valero, established in 1718, and many of the families of the Spanish soldiers who were attached to the Presidio of San Antonio de Bexar lived in the district. It became known as the little town of the Alamo and it had its own alcalde or mayor.

In the beginning, La Villita contained crude wooden structures or jacales. A Spanish inspector described the area in 1792 as having sprung up outside the walls of the abandoned mission to house the families of the soldiers who already were using the buildings and corrals of the mission. Mission San Antonio de Valero was secularized in 1793 and its lands were divided among the Indians and soldiers who lived there. More people moved into the area and began to build permanent structures after the massive flood of 1819 when the district was discovered to be on relatively high ground (Ramsdel1 1959:110-111).

Nueva Street was known as Calle a la Nueva Villa or the street to the new village. It led to the Villita district from the west side of the town. Several sources acknowledge the construction in 1810 of a Spanish quartel or fortification in the area now bounded by $E$. Nueva Street, S. Alamo Street, Arciniega Street and $S$. Presa Street. It is alleged to have played an important part in Mexico's struggle for independence from Spain. It is possible that Sra. Aldrete referred to this quartel in her petition (Santos 1965).

It is uncertain where and when Dolores Aldrete and Ygnacio Gil were married. Since Gil served in the Spanish army, it seems probable he came from another province of New Spain to the Presidio of San Antonio de Bexar and perhaps Dolores Aldrete came with him. Very little information exists about the Spanish soldiers. No 1 istings for either Dolores Aldrete or Ygnacio Gil have been found in the birth or marriage records of the San Antonio Missions or of San Fernando Cathedral. Also unestablished is how many children they had. Gil was dead by 1812 when Sra. Aldrete petitioned as a widow for a solar of land.

Sra. Aldrete married Juan Casillas after the death of her first husband, and they had at least two children, Manuel and Mariano. She is again listed as a "widow and a mother of children" in 1838 when she presented documents to the Board of Land Commissioners for a certificate for one league and labor of land she was entitled to as a resident of Texas at the time of the Declaration of Independence in 1836. A Casillas family received land at Espada Mission when it was secular- 
ized in 1824, but little is known at this time about the relationship of Juan Casillas to the Casillas family of Espada Mission (Chabot 1937:147).

According to the San Fernando Cathedral Burial Records, Dolores Aldrete died on March 27, 1852. Her sons, Manuel and Mariano, inherited lots 8 and 9 in addition to the structure situated on the rear of lot 9 where Sra. Aldrete had lived until she died. Mariano and his wife, Jesusa Ramirez, whom he had married at San Fernando Cathedral in 1851, sold the two lots to Juan Saucedo in 1854 for $\$ 400$. Lot 7 had been sold by Maria Concepcion Gil in 1848 and she stated in the deed she had acquired the property from her then deceased parents. She neglected to mention her parents' names and referred to Dolores Aldrete as living on the property west of her lot, indicating Sra. Aldrete was not her mother. Perhaps she was Maria's aunt. There is no reference in the deed records indicating when Maria received the property. Maria was probably related to Ygnacio Gil, Sra. Aldrete's first husband, and the transfer of lot 7 to Maria was apparently done by a verbal agreement. Maria may have lived on the property from 1818 until 1848 when she sold it.

Robert Caile purchased lot 8 in January 1857 for $\$ 160$ and the deed described the property as a "primitive lot." Later in the year, he acquired lot 7 for $\$ 200$. Thus it was not until 1857 that lots 7 and 8 were once again owned by one person, making it improbable that the caliche block structure presently sited on lots 7 and 8 was built by Dolores Aldrete who did not own both lots after 1848. Caile most likely built a two-room caliche block structure soon after 1857 and enlarged the structure with a brick addition during the Victorian period. Architectural investigations can determine if one of the two could have incorporated this room into the building he constructed after 1857. The Historic American Buildings Survey conducted in 1969 listed 1855 as the approximate time of construction.

Lot 9 sold several times after 1854 independently of the other two lots. Indications of the various owners can be seen in the different additions to the original palisado structure.

Caile came from England to Texas, and he and his wife, Lola, had four children, Mary, Lizzie, Carrie and Annie. The Cailes owned and lived on the property described in the deed records as the "Caile Homestead" from 1857 until 1894. The Historic American Buildings Survey taken in 1969 stated Caile rented a store building in the neighborhood about 1860; however, its location has not been determined. A tax suit filed against Robert Caile by the City of San Antonio in 45th District Court in 1893 indicated taxes had not been paid from 1877 to 1891 . The property value in 1877 was assessed at $\$ 800$ and the improvements at $\$ 1200$. By 1891 the value of the property had increased to $\$ 900$, but the value of the improvements had remained the same. The Cailes owed $\$ 337.47$ in delinquent taxes. The taxes were apparently paid because the city dismissed the suit.

Caile, also spelled Cail, was a noted gambler in San Antonio. He was accused of attempted murder in 1854 in the City of San Antonio vs. Robert Cail. Witnesses testified that Caile drank all the time and "he did not know what he did or said when he was drunk." It was at Hickey's House, a local bar, that Caile shot $\mathrm{Mr}$. John Hickey in the face. Hickey recovered, but Caile was jailed and bond set at $\$ 2000$. The jury found Caile guilty and sentenced him to 30 days imprison- 
ment (article by Mr. Elton Cude, Bexar County District Clerk). Caile was also arrested three times during the year 1878 for "dealing monte" or gambling with cards. Caile died at the age of 61 and was buried January 14, 1879, in the City Cemetery No. 1 (City Cemetery Records, San Antonio).

Lola Caile and the children continued to live in the house on East Nueva Street after Caile died. She sold the property, lots 7 and 8, to Jacob Hotz in 1894 for $\$ 2200$. Hotz had purchased lot 9 in 1885 for $\$ 1100$. The three lots once again came together as one piece of property and they continued to sell as a unit. No Caile family is listed in the San Antonio City Directory after 1897. Where Mrs. Caile died or was buried is unknown and no relatives have been 10cated in San Antonio.

The City Directory listed Hotz as a farmer. His father was a dairyman and owned land on S. Presa Street at the corner of E. Mitchel1 Street. Hotz, a single man, rented the property on E. Nueva Street and never lived there himself, according to the City Directory.

In 1927 the City paid Hotz about $\$ 5,220$ for portions of lots 7,8 and 9 to be used for the widening and paving of $E$. Nueva Street. Hotz was responsible for removing all the buildings on the property sold; therefore, there may have been other structures on the land. Hotz died in 1928 and the property passed to his sister and then to her children during whose ownership it served as residential rental property until the 1940s.

\section{METHODOLOGY}

During March and April 1978, two archaeologists, Daniel E. Fox and Fred Valdez, Jr., from the Center for Archaeological Research, UTSA, spent five days at the Dolores Aldrete House property. In order to study the construction and condition of foundations, to retrieve archaeological data with which to interpret the chronology and function of site occupation and to evaluate the archaeological potential of the site, six test pits of varying dimensions and two $50 \mathrm{~cm}^{2}$ shovel tests were excavated (Fig. 2).

Test pits 1 and 2 were placed into the fill below the wood floor, against the west wall in the northwest room of the Caile House (Fig. 4,a,b; Fig. 5,a). The dimensions of these units $(70 \times 105 \mathrm{~cm}$ and $70 \times 95 \mathrm{~cm}$, respectively) were determined by the amount of tongue and groove flooring removed by contractors in advance of archaeological work. Test pit $3(50 \times 100 \mathrm{~cm})$ was placed outside the Caile House, against the west brick wall of the southwest room (Fig. 5,b).

Test pit $4\left(1 \mathrm{~m}^{2}\right)$ was located on the north side of the palisado house (lot 9), adjacent to its concrete front porch (Fig. 6,a). Test pit $5(33 \times 88 \mathrm{~cm})$ was excavated through a hole in the $1 \times 12$ inch wood flooring inside and against the north jacal wall of the palisado house (Fig. 6,b). Test pit $6(40 \times 70 \mathrm{~cm}$ ) was placed outside, near the corner, against the east board-and-strip wall of the palisado house.

Shovel tests 1 and 2 were dug into the yard (lot 9), north of the palisado house and west of the Caile House. 


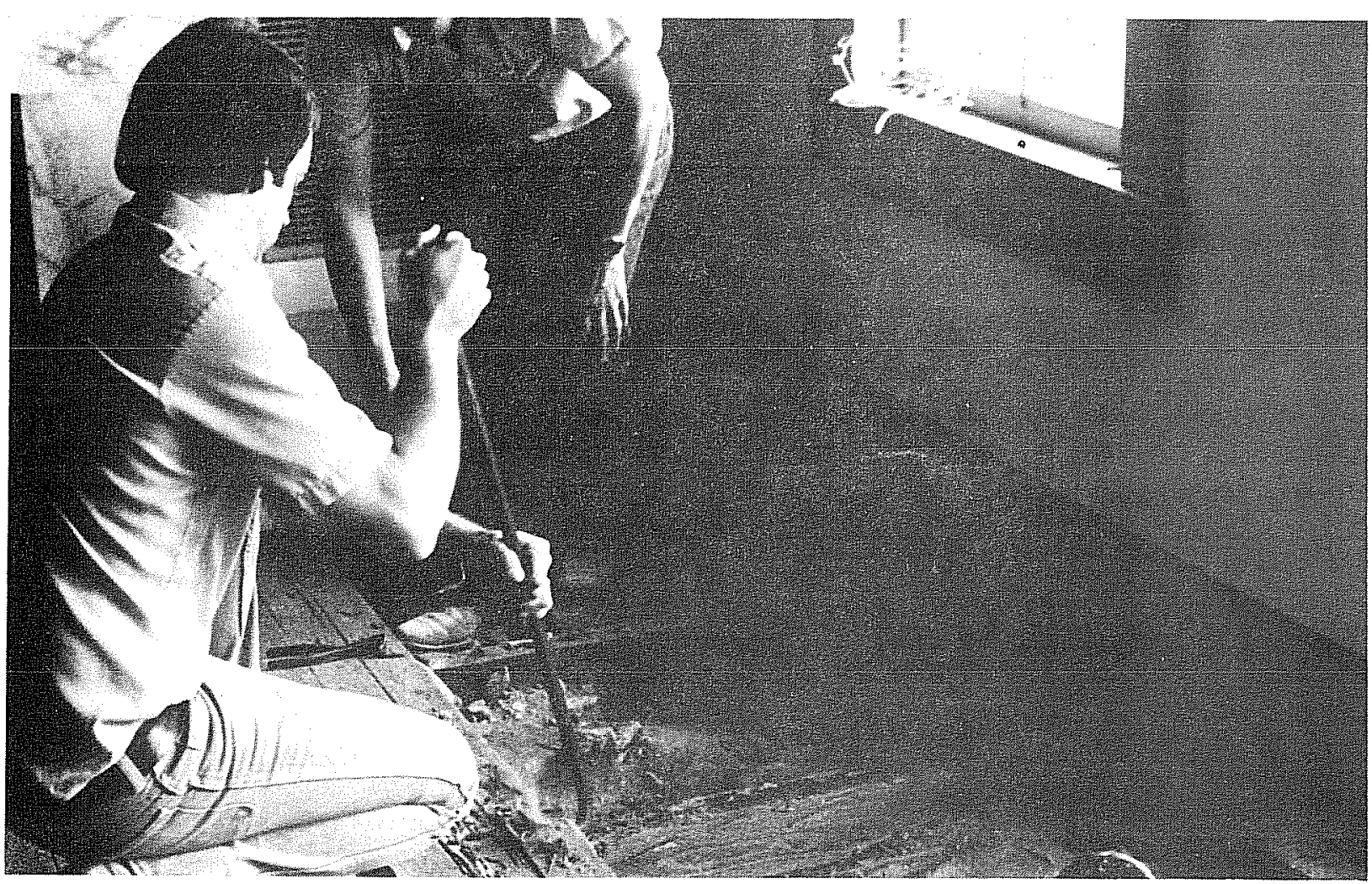

a
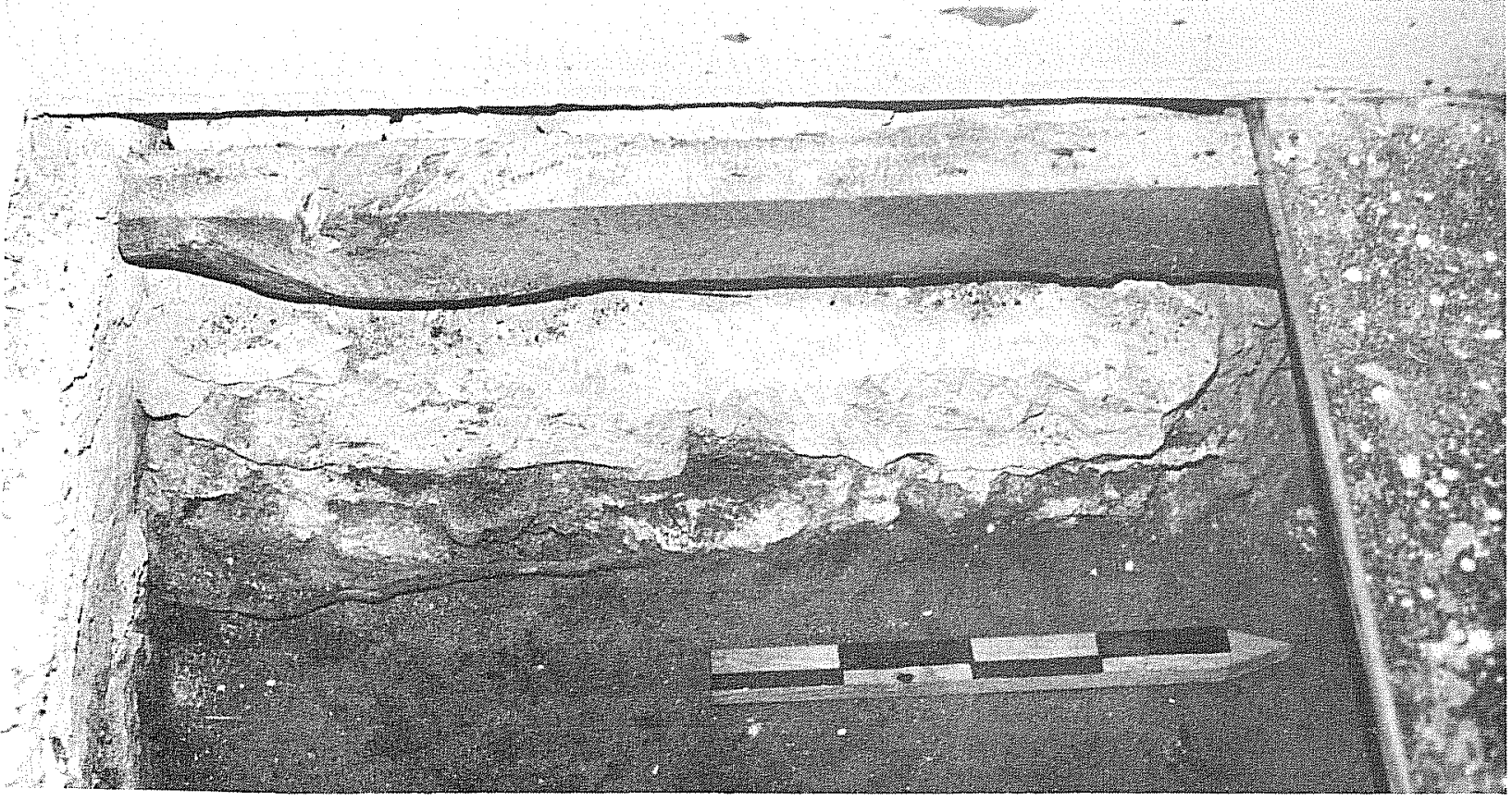

b

Figure 4. Test Pit 1. a, contractors removing wood flooring in northwest room of Caile House; b, west profile of Test Pit 1 (note floor joist and foundation stones) 


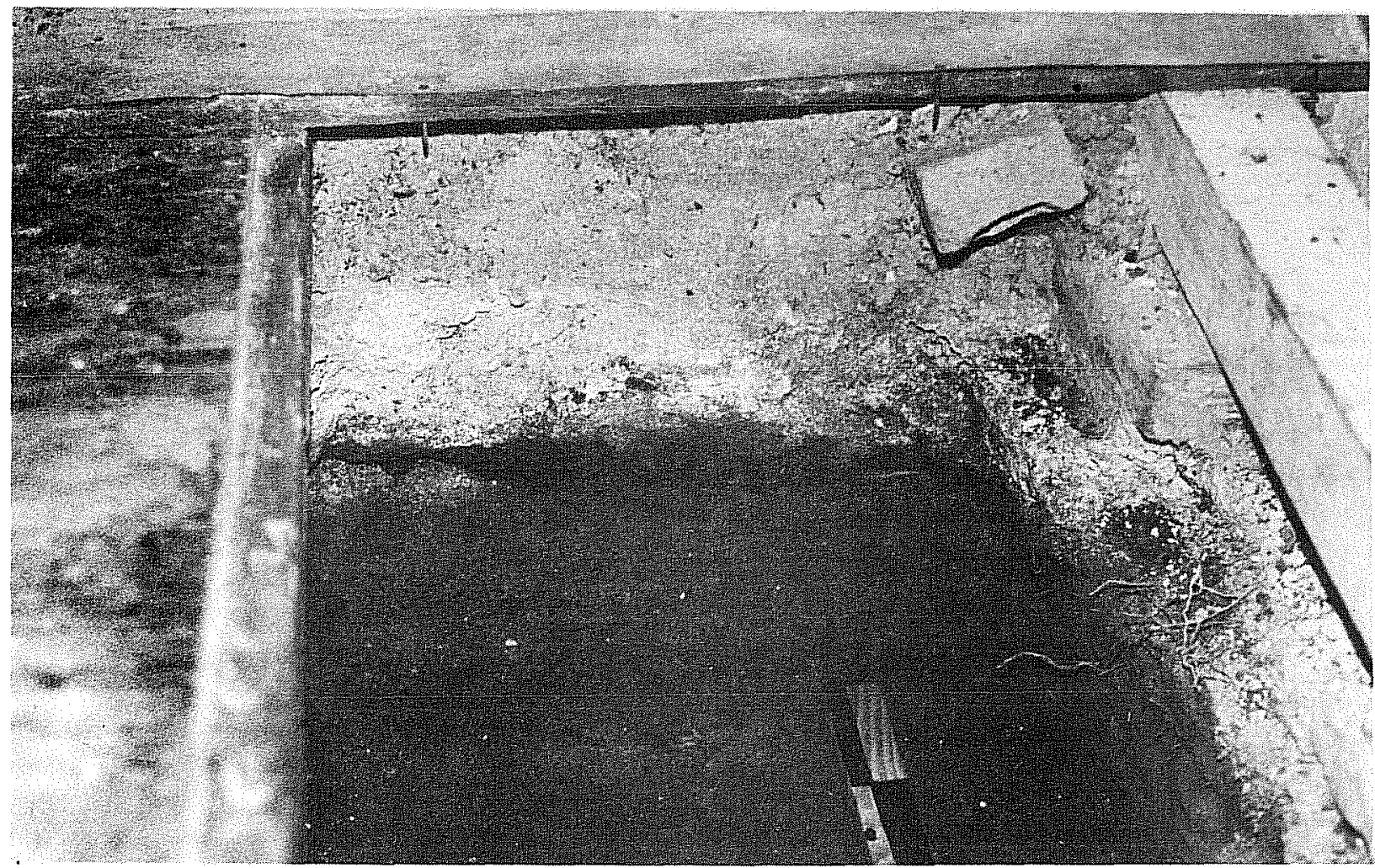

a

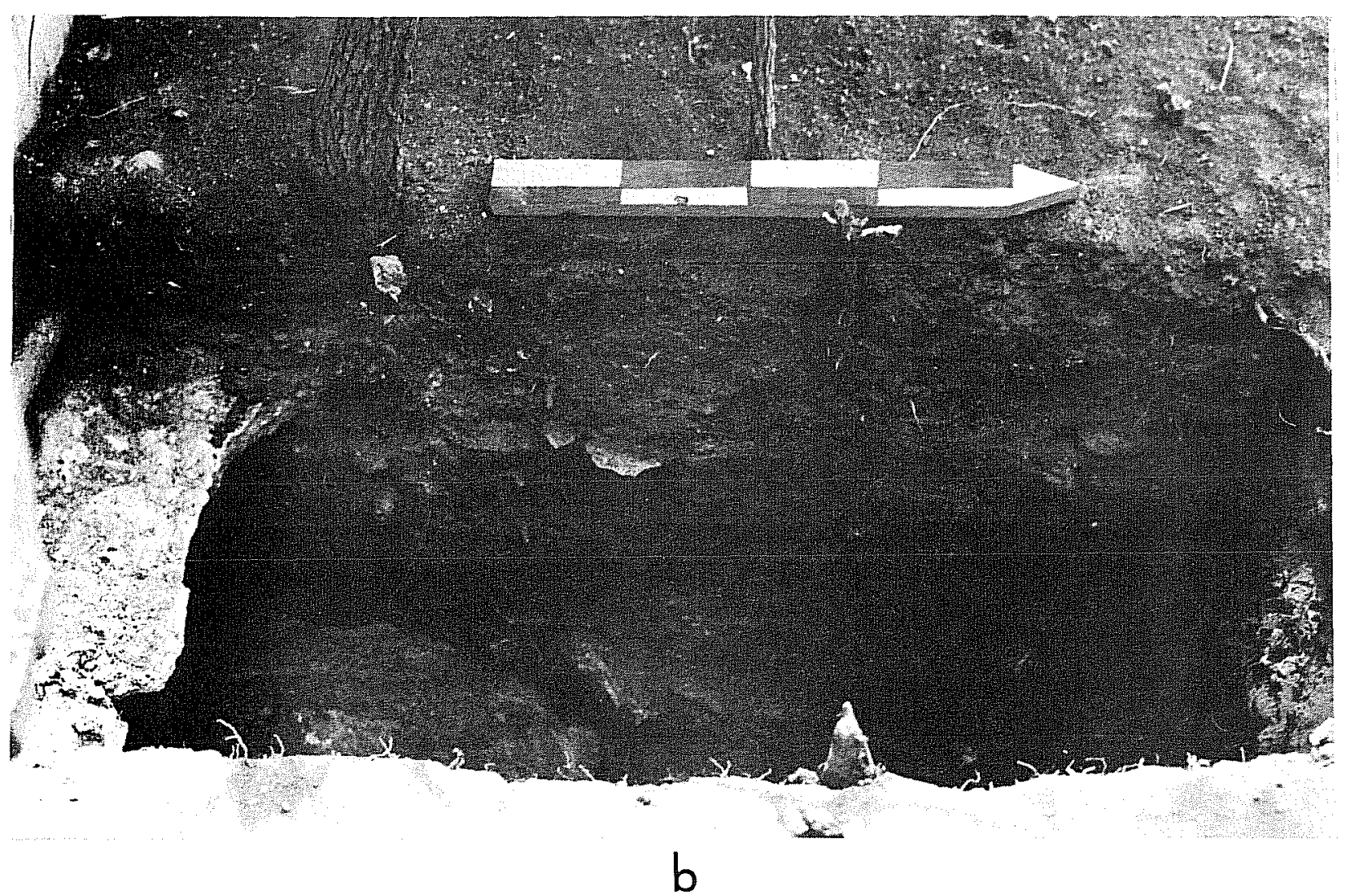

Figure 5. Test Pits 2 and 3. a, south profile of Test Pit 2 in Caile House (note fill overlying dark preconstruction soils); b, south profile of Test Pit 3 in Caile House (note 20th century foundation and "bedrock"). 


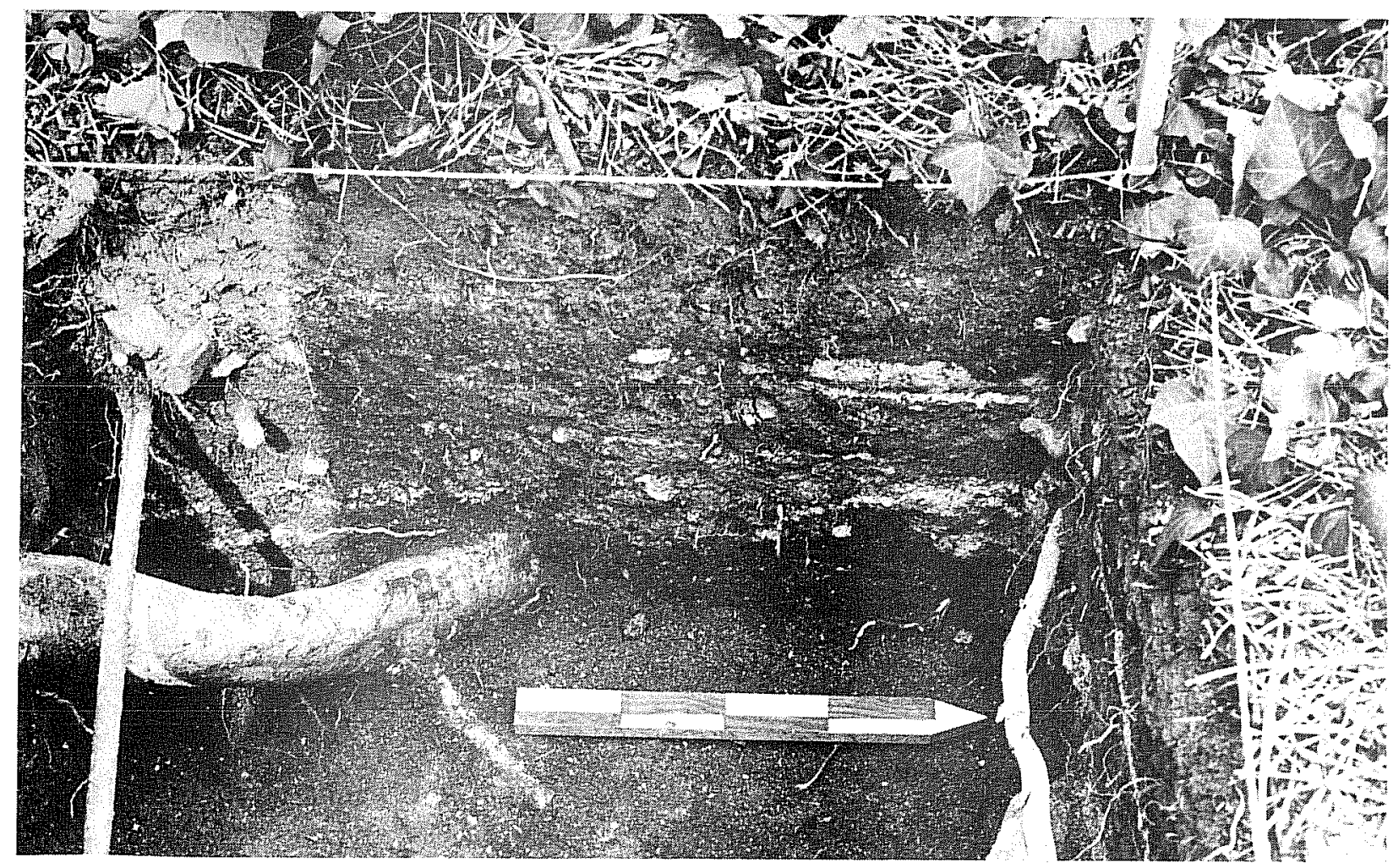

a

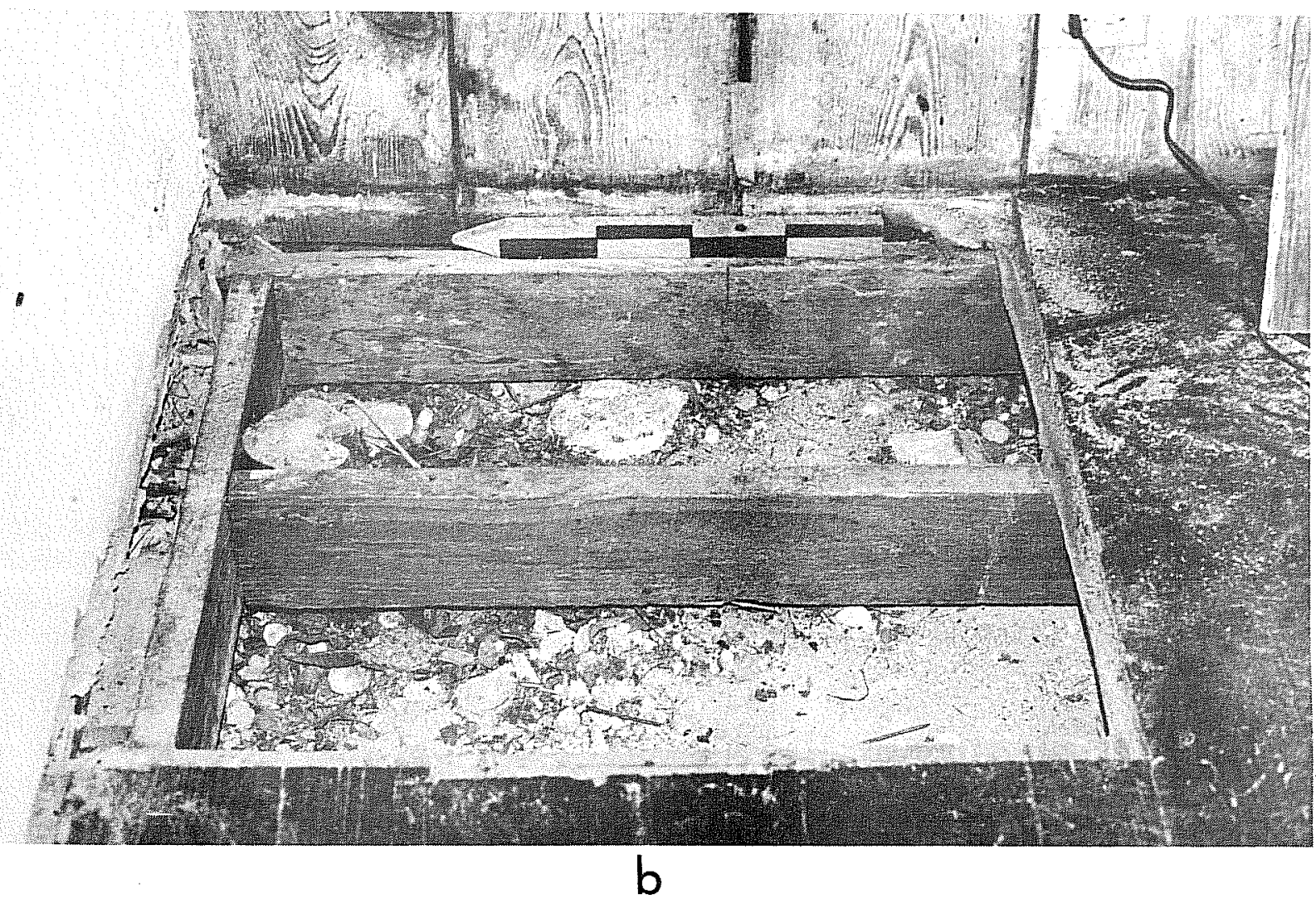

Figure 6. Test Pits 4 and 5 . a, west profile of Test Pit 4 in Caile House (note water line, roots, layers of $f i 11$ ); b, surface below wood floor in southeast corner of Dolores ATdrete (Palisado) House. 
As often as possible, fill zones were excavated as units. Thin arbitrary levels were removed when cultural layers of fill could not be recognized. For test pits 1-3, depths were measured from the surface of the wood floor in the northwest room of the Caile House. For test pits 4-6, the wood floor of the palisado house was used as the elevation datum. Depths of shovel tests 1 and 2 were measured below the relatively level ground surface of the yard (approximately $8 \mathrm{~cm}$ below the wood floor of the Caile House).

A11 excavated deposits were screened through 1/4-inch mesh hardware cloth. Samples from various substrata were screened through $1 / 8$-inch mesh screen. A11 field work was documented thoroughly with notes, maps, drawings and photographs.

Recovered samples of cultural material were transported to the Archaeology Laboratory at UTSA where they were cleaned, catalogued and inventoried. Field records are filed at the Center for Archaeological Research, UTSA. Selected cultural materials will be returned to the property owners by request.

\section{STRUCTURAL FEATURES}

Six archaeological features associated with construction of the Caile and palisado houses were encountered within test pits 1,2,3 and 5. Brief descriptions of these features are presented below.

\section{Caile House Stone Foundation (test pits 1 and 2)}

One course of large, dressed limestone slabs forms the foundation which supports the tufa limestone west wall and west fireplace of the Caile House. These foundation stones apparently were laid upon the ground surface, $35 \mathrm{~cm}$ below the surface of the existing wood floor in the northwest room of the structure (Fig. 4,b; 7,b).

\section{Caile House Brick Facade (test pit 1)}

A red brick wall probably was added during the 1920s to replace the original north tufa 1 imestone wall of the Caile House. The foundation trench for the brick facade penetrated and disturbed the fill deposits below the wood floor and the northern end of the limestone foundation of the west stone wall of the house. The interior side of the 19 th century north stone wall probably was originally located some $80 \mathrm{~cm}$ to the north of the interior of the existing brick wall (Fig. 7,b).

\section{Caile House Concrete Foundation (test pit 3)}

A concrete footing supports the west wall of the brick and frame addition to the south side of the Caile House. Apparently concrete was allowed to splash outward from beneath the forming lumber to create a waterproofing for the foundation (Fig. $5, b ; 7, c)$. 


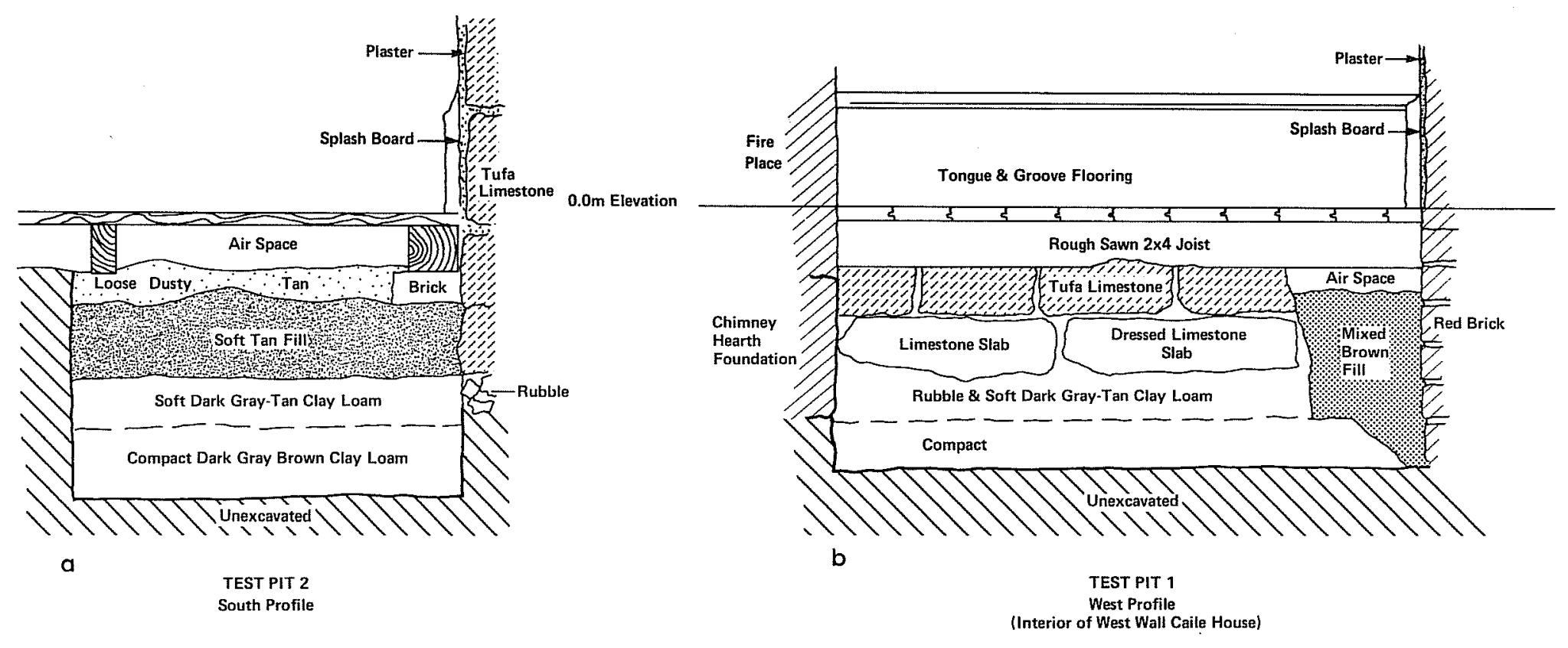

\begin{tabular}{l}
0.1 \\
\hline \\
\hline
\end{tabular}

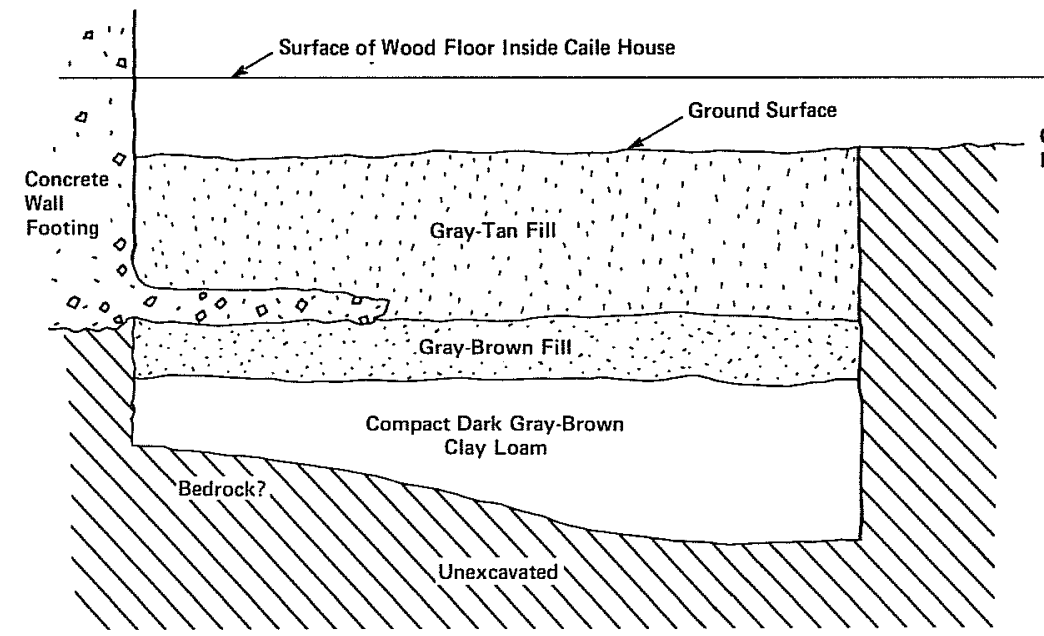

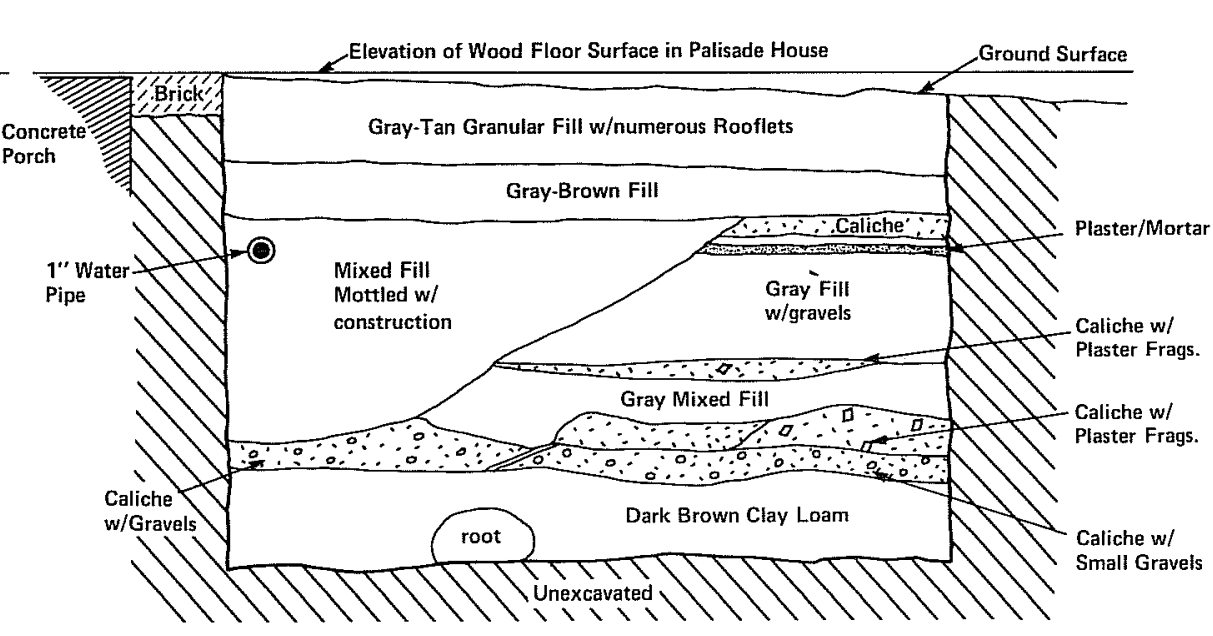

d

TEST PIT 4

Figure 7. Profiles of Test Pits $1,2,3$ and 4 . 
Palisado House Upper Plaster Floor (test pit 5)

The surface of a plaster floor averaging $8 \mathrm{~cm}$ thick lies approximately $42 \mathrm{~cm}$ below the surface of the existing wood floor of the palisado house (Fig. 8).

Palisado House Lower Plaster Floor (test pit 5)

A more deteriorated plaster floor averaging $2 \mathrm{~cm}$ thick lies approximately $56 \mathrm{~cm}$ below the surface of the existing wood floor of the palisado house. A fill zone averaging $5 \mathrm{~cm}$ thick separates the upper and lower plaster floors. Construction and preconstruction soils are directly below the lower floor (Fig. 8).

\section{Palisado House wall Foundations (test pit 6)}

Cedar posts support the east board-and-strip wall of the palisado house. Concrete appears to have been poured into a shallow trench running along the base of this west wal1, perhaps in an attempt to prevent animals from entering the air space beneath the wood floor of the structure. No evidence of a palisado, or jacal, foundation was recognized in test pits 5 or 6 . Further interpretation of methods of jacal wall construction should be based on inspection of above-ground structural evidence, since 20th century construction activities apparently have destroyed or obscured buried structural remains.

\section{CULTURAL STRATIGRAPHY}

Soil zones penetrated by test excavations include 19th and 20th century fill deposits, plaster floors, an original 19th century ground surface and preconstruction (18th century and earlier) soils. Below is a summary of the cultural stratigraphy as it was encountered in test pits 1-6 and shovel tests 1 and 2 . Root, rodent and/or construction disturbances were observed in each test.

Test Pits 1 and 2 (Fig. 4,b; 5,a; 7,a,b)

A thin layer of loose, dusty soil and cultural material forms the present surface below the wood floor in the northwest room of the Caile House. Below this, a soft layer of tan fill rests on a soft dark gray-tan clay loam which probably was the ground surface during the construction of the structure. Within this zone, puddles of plaster (or mortar?) were found in test pit 2. Preconstruction soil is a compact dark gray-brown clay loam. Along the north wall of the Caile House, these deposits have been disturbed by the excavation of a foundation trench for the placement of the 20 th century brick facade.

Test Pit 3 (Fig. $5, \mathrm{~b} ; 7, \mathrm{c}$ ) and Shovel Tests 1 and 2

Outside the west wall of the Caile House and in the yard to the north of the palisado house, layers of gray-tan soil containing caliche and cultural material make up fill deposited primarily (apparently) during the 20th century. Below this, a dark gray-brown clay loam mixed with fill probably forms the early 19th 


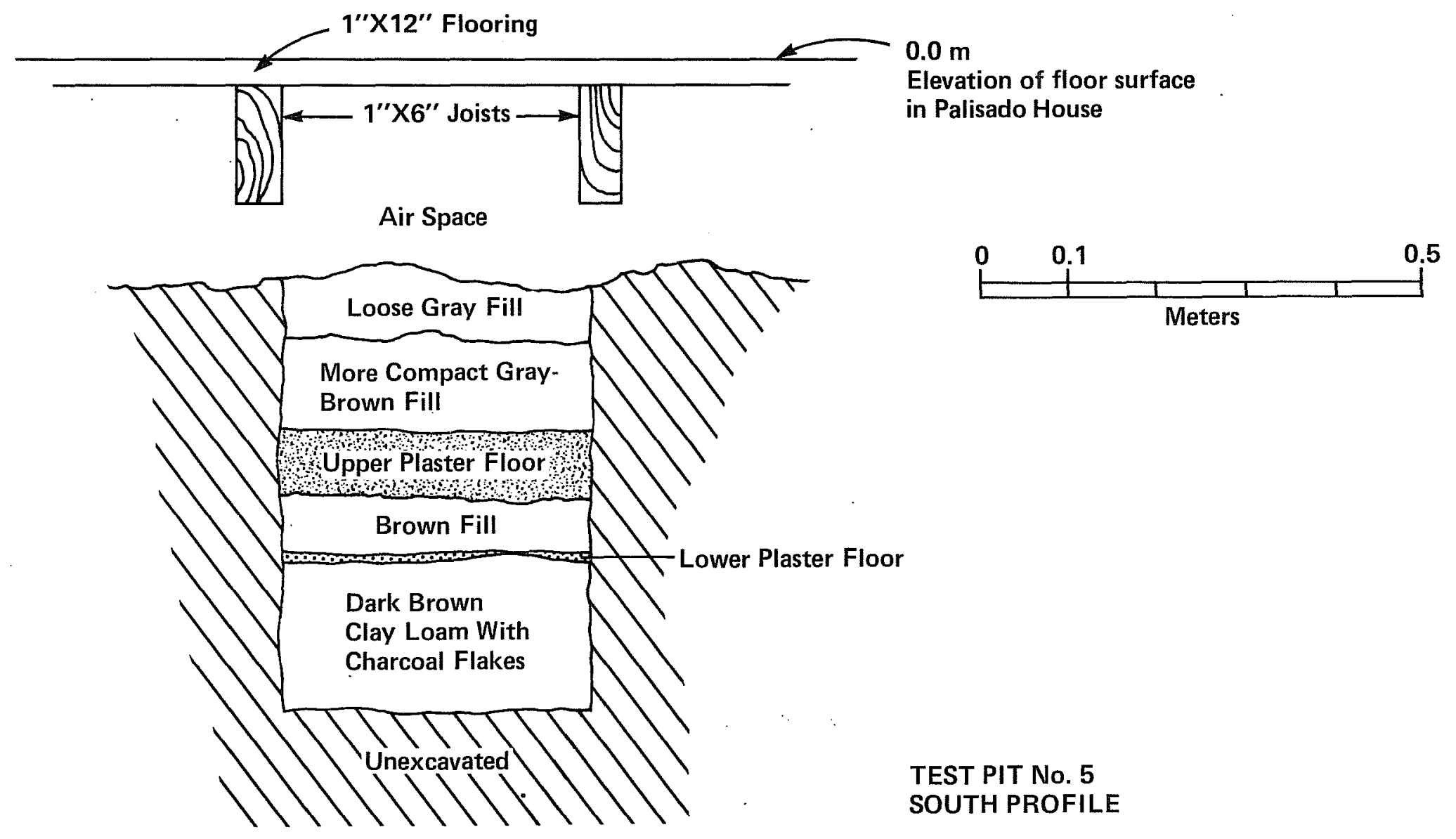

Figure 8. Profile of Test Pit 5. 
century ground surface. Preconstruction soil is a dark gray-brown clay loam containing fragments of limestone and a thin scatter of chipped stone cultural debris. In test pit 3, this soil was found to rest on the undulating surface of a substantial limestone bedrock formation.

Test Pit 4 (Fig. $6, \mathrm{a} ; 7, \mathrm{~d}$ )

In front of the palisado house, off the existing concrete porch, a thick, complex series of fill layers was found to rest on the dark gray-brown clay loam preconstruction soil. Various layers and lenses containing variable amounts of caliche, clay loam and plaster mixed with relatively large amounts of construction debris and other cultural material probably represent several periods of construction and maintenance of the palisado house during the 19th and 20th centuries.

Test Pit 5 (Fig. 6,b;8)

Beneath the existing wood floor of the palisado house, a thin layer of loose dusty soil and cultural material forms the ground surface. Below this, a soft layer of fill rests on a plaster floor. A thin layer of fill separates this structural feature from a thinner, more deteriorated plaster floor which rests on the dark gray-brown clay loam that probably underlies the general site area.

Test Pit 6

The area outside, along the east board-and-strip wall of the palisado house, has been disturbed by 20th century excavations for the construction and renovation of the wall and for the placement of sewer and gas lines.

\section{CULTURAL MATERIALS}

Reflected in the sampling of cultural materials are many cultural aspects of the 19 th and 20th century occupation of three small lots in the La Villita neighborhood of downtown San Antonio. Tables 1,2,3 and 4 present the classification and provenience of 2,326 individual artifacts and of 37 samples of other archaeological materials. Further descriptive and background information about the various categories of cultural material can be found in several publications concerning archaeological investigations at historic sites in San Antonio (e.g. Tunnel1 1966, Greer 1967, Schuetz 1969, Fox 1970, Fox, Bass and Hester 1976, Scurlock and Fox 1977 and Eaton n.d.a; n.d.b).

Construction materials (Fig. 9,a-h) consist of debris produced by 19 th and 20 th century carpentry, masonry, electrical and plumbing work which was done during several periods of construction, maintenance and renovation of the two extant structures. Household garbage (Fig. 10,a-f) represents the residential nature of the 19th and early 20th century occupation of these buildings, as do food related materials (Fig. 11, a-n; 12,a-e). Coconuts, pecans, eggs, peaches and candy probably were among the foods consumed by the site's inhabitants--people and rodents. Numerous bone fragments, many of which have been cut or sawn, are the remains of a variety of domesticated animals, such as cattle, fowl, sheep and/or goats and wild fauna, such as rabbit, deer and fish. The bones of a pet dog and cats were also found. 

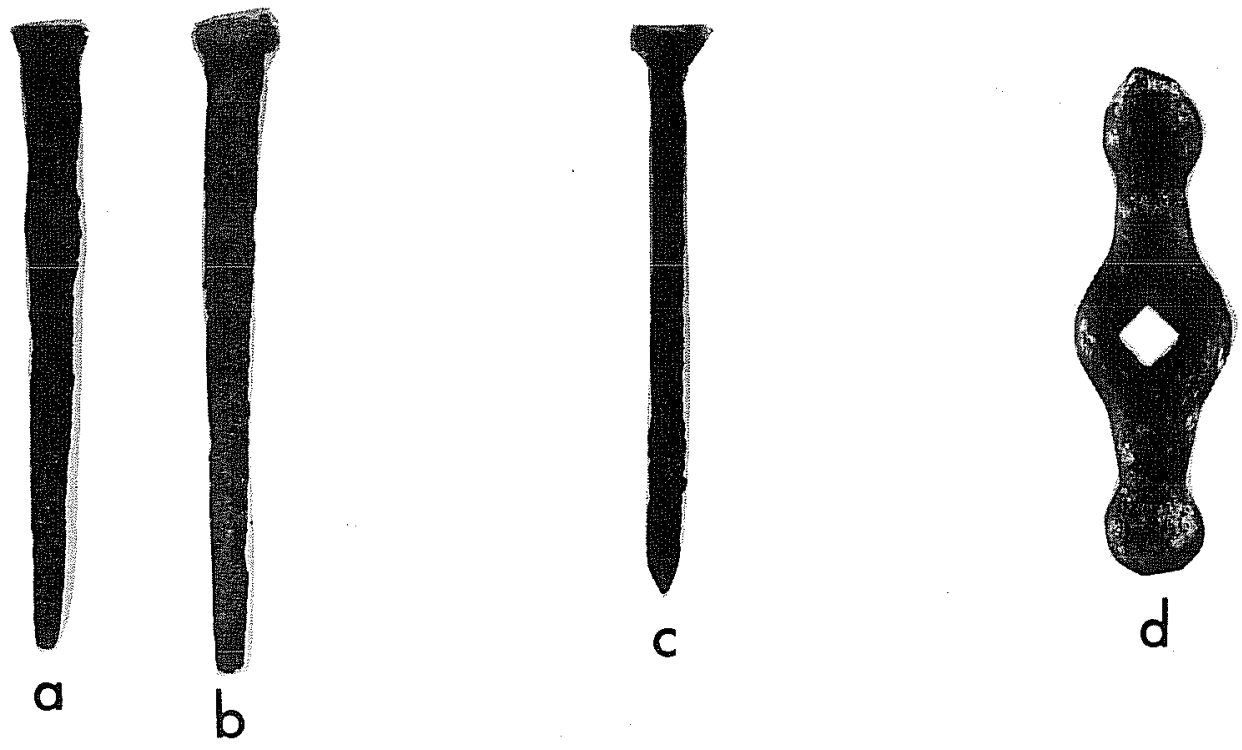

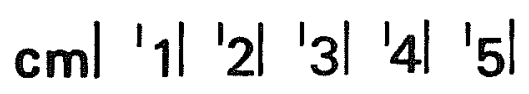

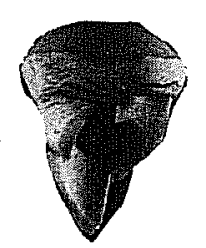

e
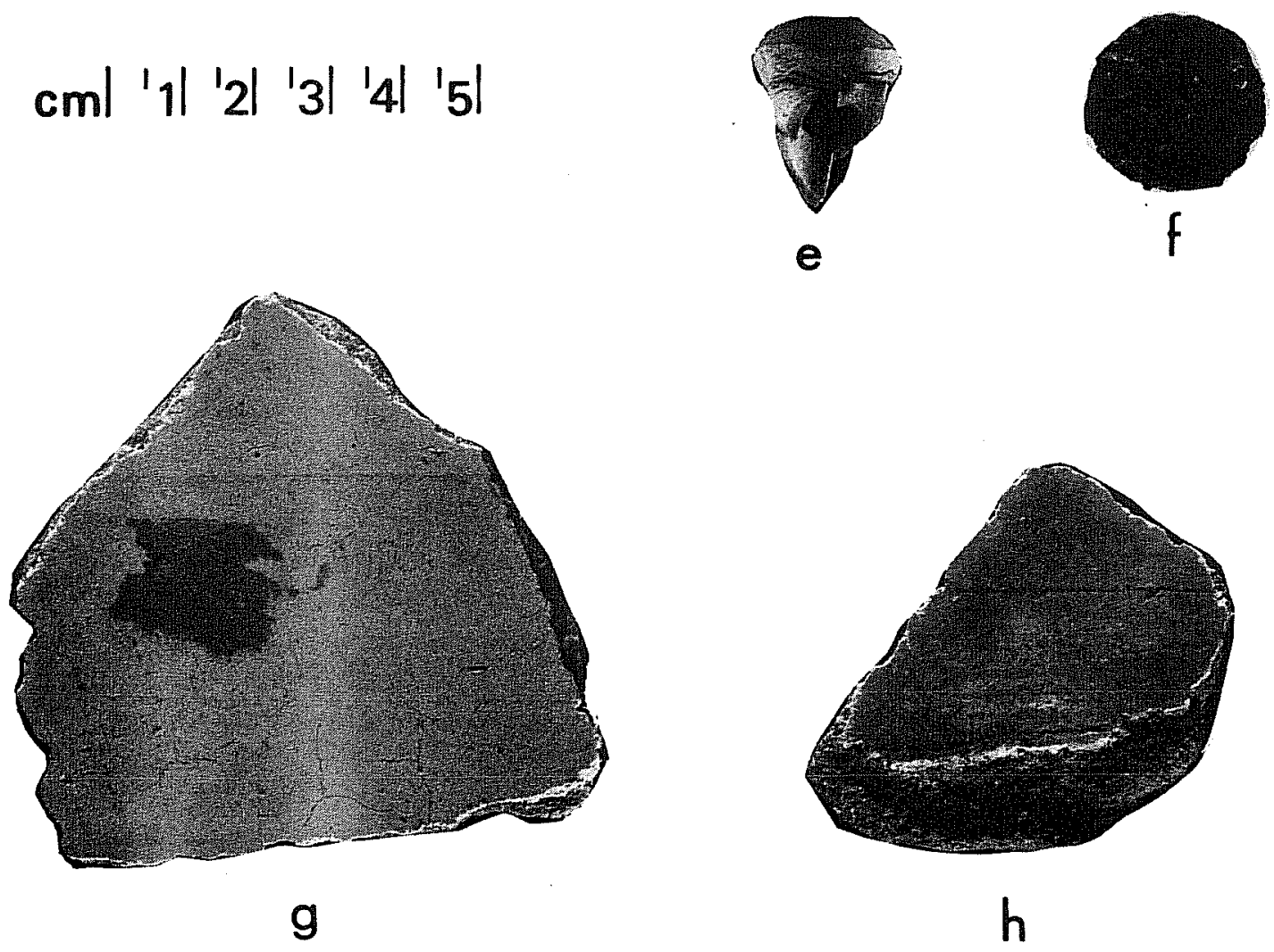

h

Figure 9. Selected Artifacts, Construction Materials. $a$ and b, square nails; $c$, wire nail; d, faucet handle; e, porcelain insulator fragment; $f$, slug; $g$, white-painted plaster; $h$, gray-painted plaster. 


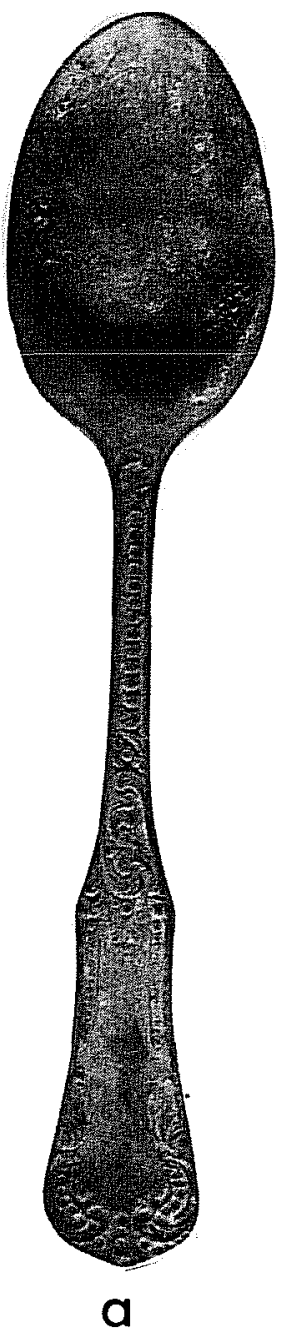

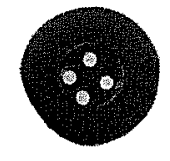

g

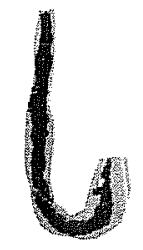

m
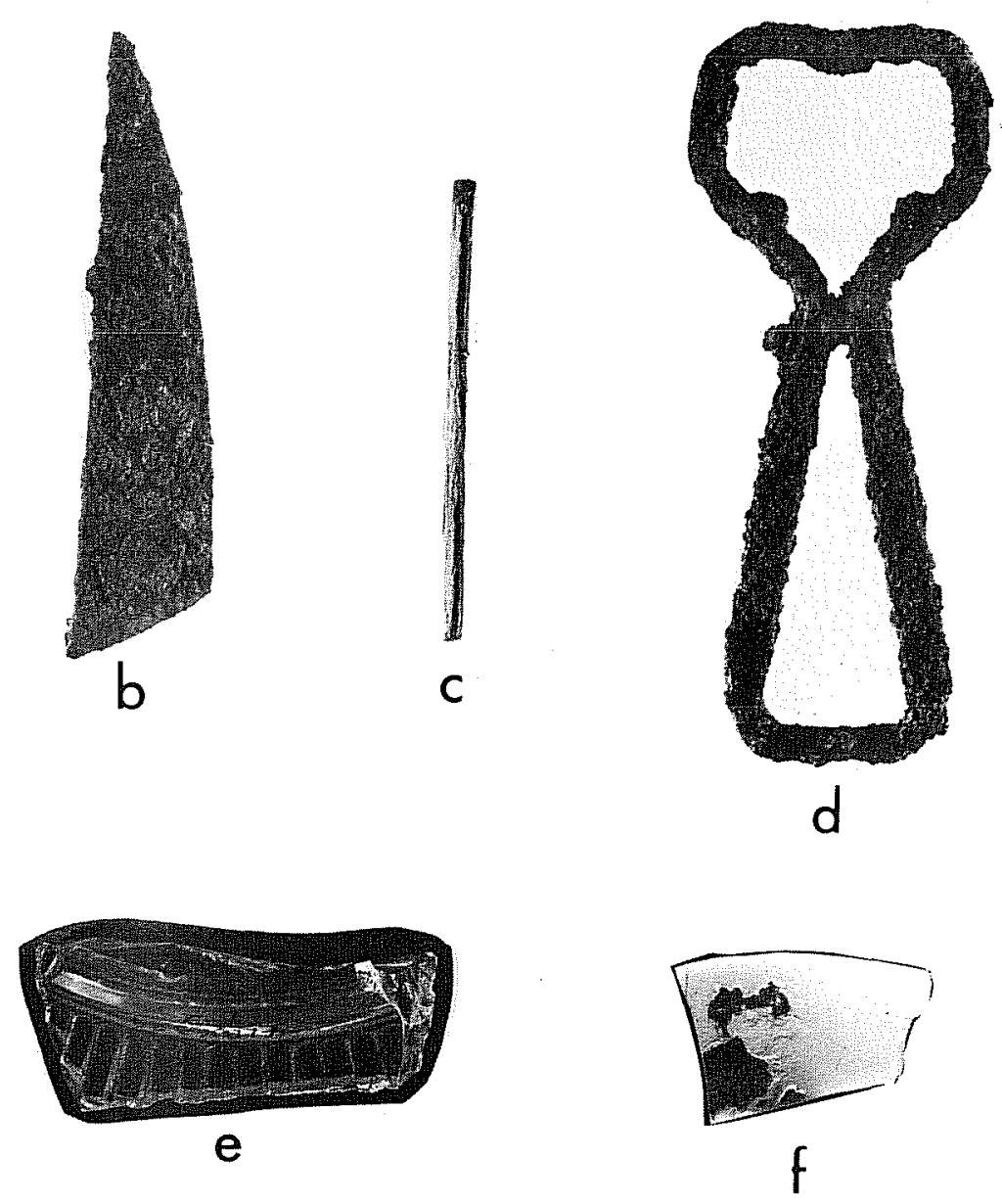

\section{$\left.\left.\left.\left.\left.\mathrm{cm}\right|^{\prime} 1\right|^{\prime} 2\right|^{\prime} 3\right|^{\prime} 4\right|^{\prime} 5 \mid$}
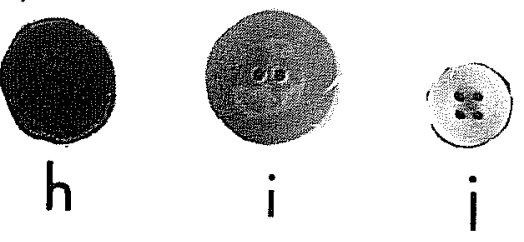

$(0)$

k
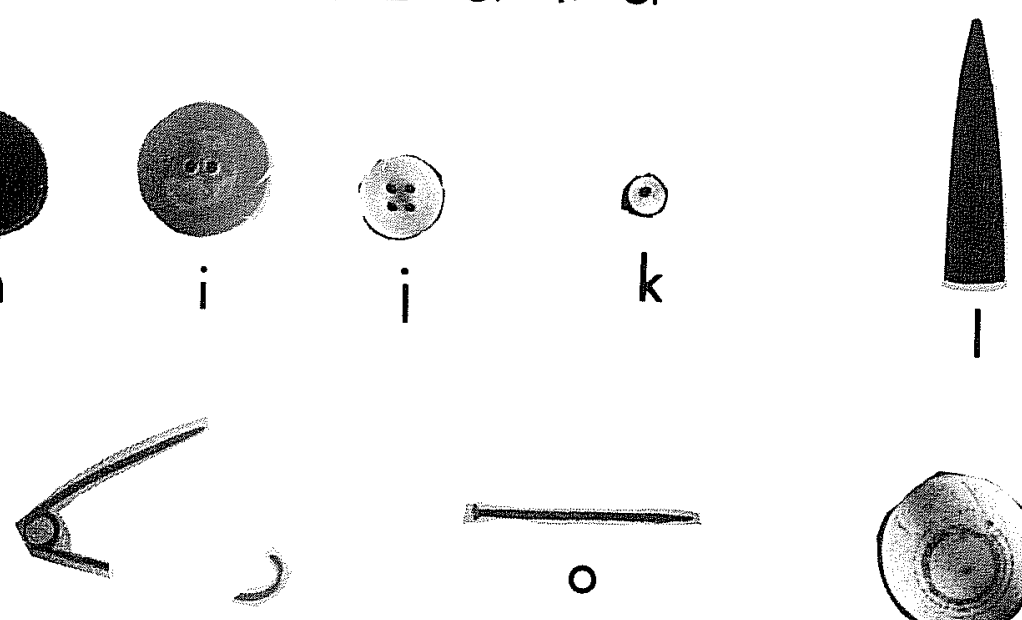

n

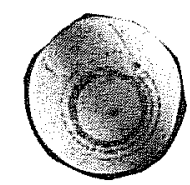

P

Figure 10. Selected Artifacts, Household and Personal Items. a, spoon; b, knife blade fragment; c, match stick; d, bottle opener; e, oil lamp fragment; $f$, painted lamp chimney fragment; $g$, bone button; $h$, brass button; $i$, shell button; $j$, porcelain button; $k$, bead; 1 , comb fragment; $m$, fish hook; $n$, safety pin; 0 , straight pin; $p$, marble. 

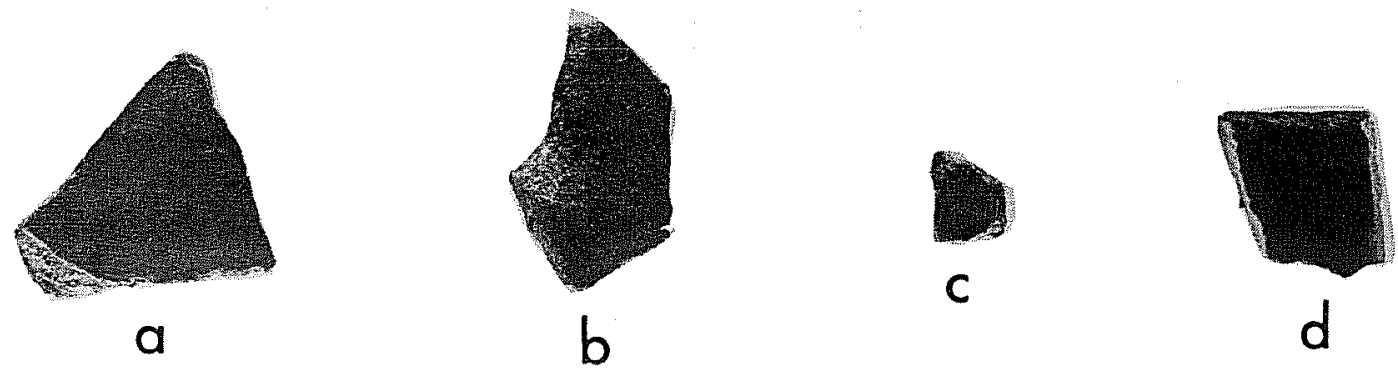

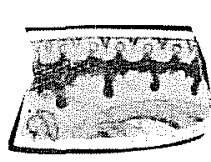

e

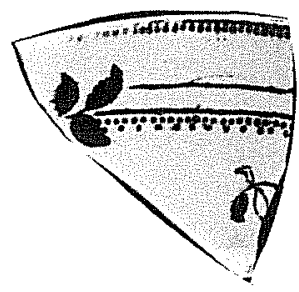

f
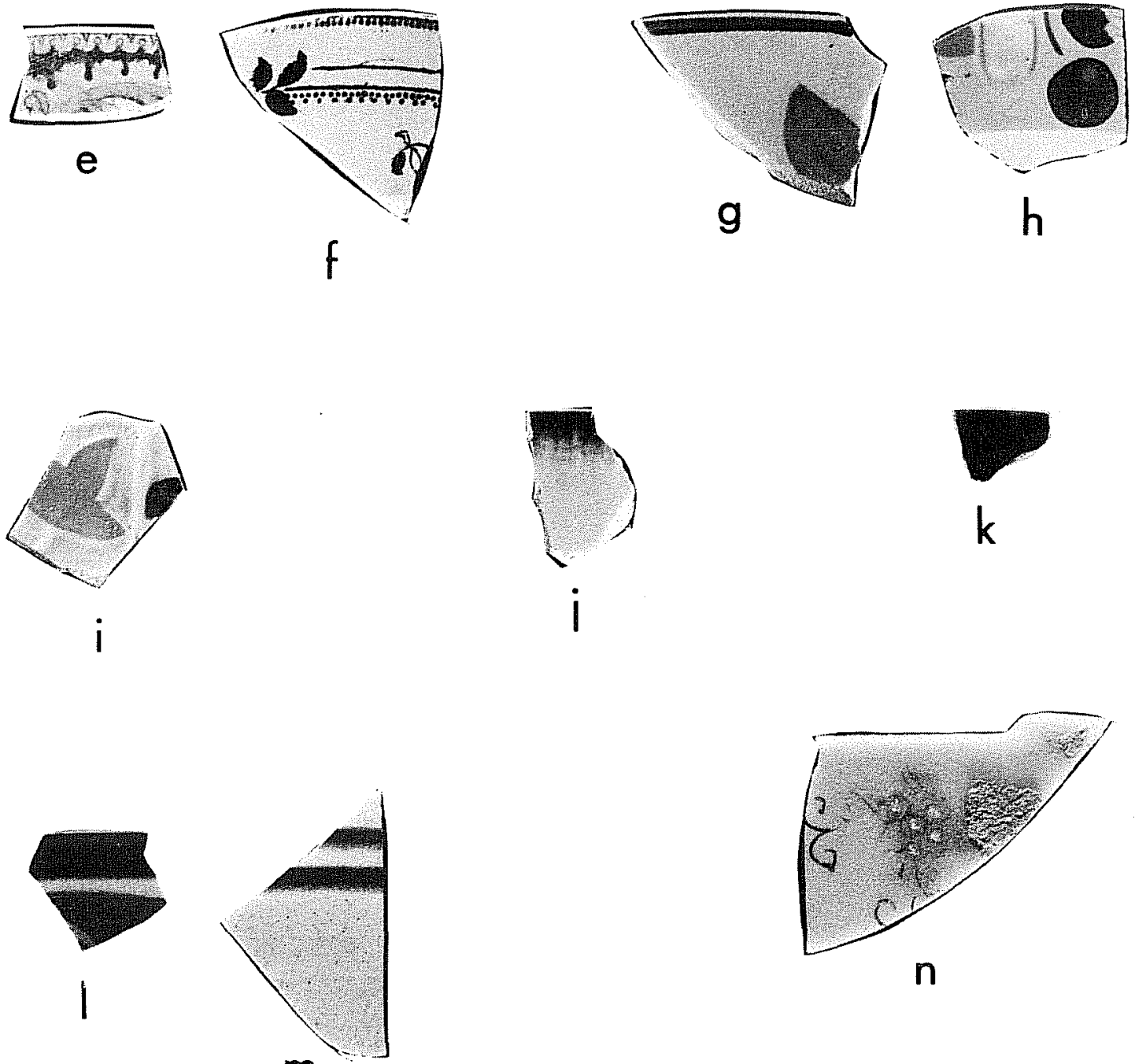

h
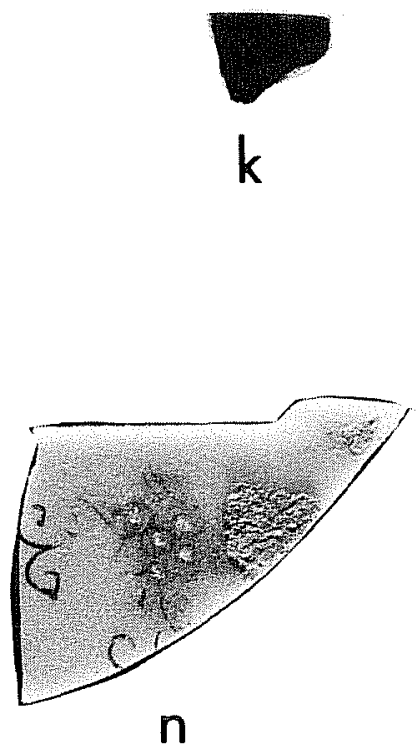

m

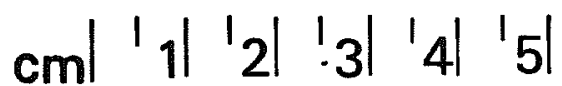

Figure 11. Selected Artifacts, Kitchen Materials (Pottery). a, Goliad ware; $b$, fugitive red painted; $c$, tin enameled; $d$, lead glazed; e and $f$, transfer painted; $g$ and $h$, hand painted; $i$ and $j$, molded hand-painted edgeware; $k$, blue flown; 1 and $m$, Mocha ware; $n$, painted porcelain. 

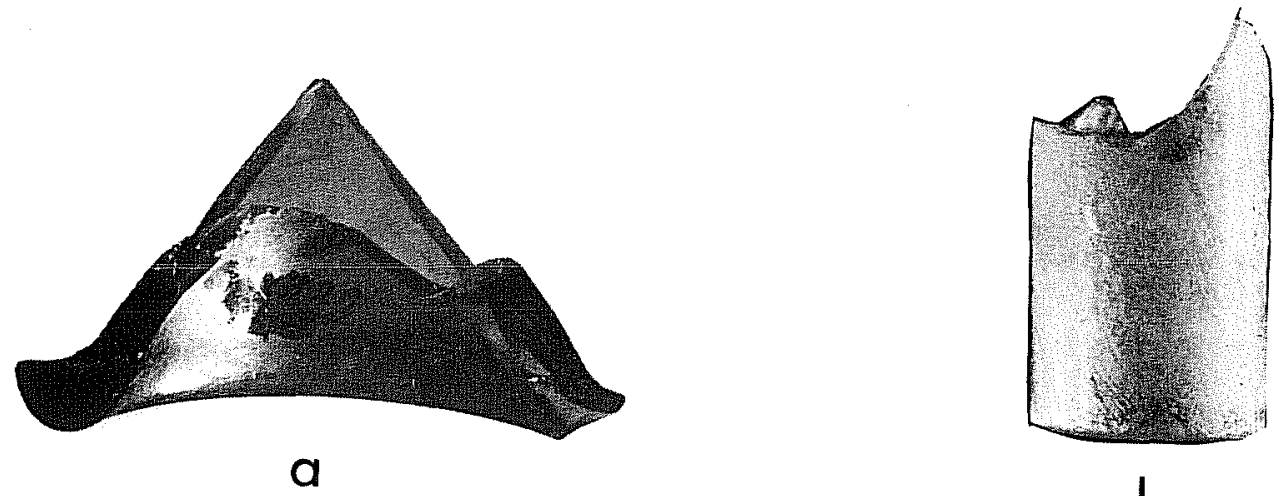

b
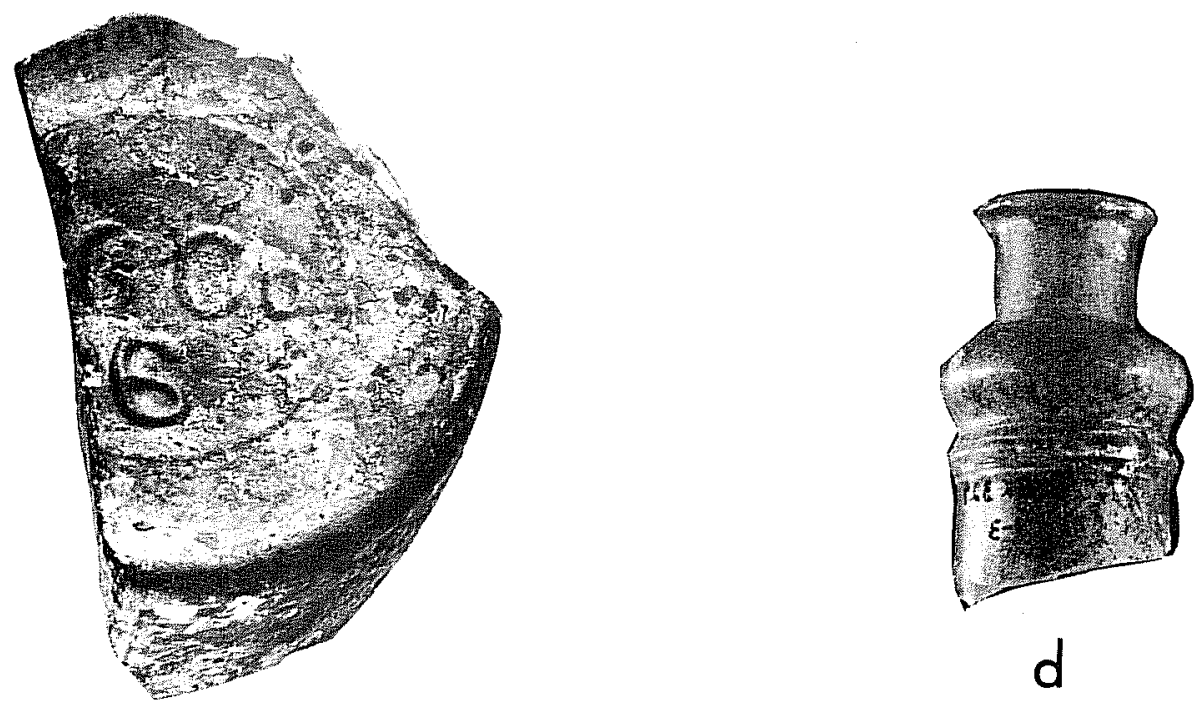

C

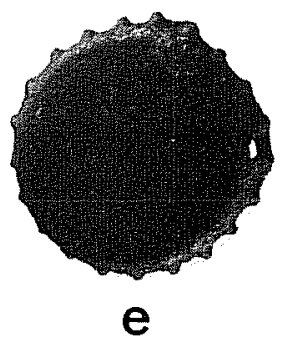

$\left.\mathrm{cm}\left|{ }^{\prime} 1\right|^{\prime} 2\left|{ }^{\prime} 3\right|{ }^{\prime} 4\right|^{\prime} 5 \mid$

Figure 12. Selected Artifacts, Kitchen Materials (Glass Bottles). a, olive green; b, aquamarine; c, brown; d, clear; e, crown cap. 


\begin{tabular}{|c|c|c|c|c|c|c|c|c|c|c|c|c|c|c|c|c|c|c|c|c|c|c|c|c|c|c|c|c|c|c|c|c|c|c|c|c|c|c|c|c|}
\hline & \multirow[b]{2}{*}{$\begin{array}{l}\text { TABLE } 1 \\
\text { Dolores Aldrete House } \\
\text { Construction Materials } \\
\text { and Proveniences }\end{array}$} & \multicolumn{6}{|c|}{ TP 1} & \multicolumn{6}{|c|}{ TP 2} & \multicolumn{4}{|c|}{ TP 3} & \multicolumn{5}{|c|}{ TP 4} & \multicolumn{7}{|c|}{ TP 5} & \multicolumn{3}{|c|}{ TP 6} & \multicolumn{4}{|c|}{ ST 1 . } & \multicolumn{3}{|c|}{ ST 2} & \multirow[b]{2}{*}{\begin{tabular}{|c} 
\\
0 \\
$\frac{3}{5}$ \\
5 \\
\end{tabular}} \\
\hline & & 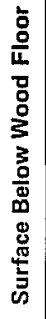 & 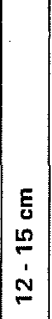 & 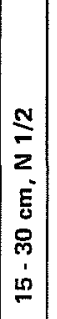 & 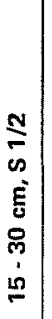 & 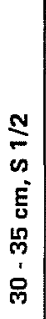 & $\begin{array}{c}E \\
E \\
0 \\
f \\
i \\
n \\
m\end{array}$ & 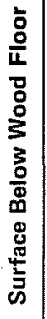 & $\begin{array}{c}E \\
0 \\
\mathbb{N} \\
\dot{0} \\
\stackrel{2}{*}\end{array}$ & $\begin{array}{c}E \\
0 \\
\stackrel{p}{ } \\
\dot{N}\end{array}$ & $\begin{array}{c}E \\
0 \\
\dot{m} \\
\dot{g} \\
\dot{m}\end{array}$ & 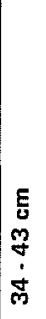 & 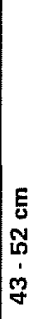 & $\mid \begin{array}{c}E \\
0 \\
o \\
\text { N } \\
\vdots \\
O\end{array}$ & 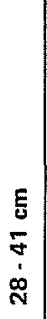 & $\begin{array}{c}\varepsilon \\
0 \\
5 \\
\vdots \\
\dot{y}\end{array}$ & $\begin{array}{l}E \\
E \\
0 \\
0 \\
\dot{1} \\
10\end{array}$ & 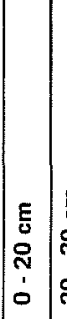 & 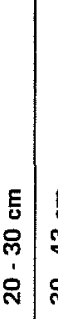 & 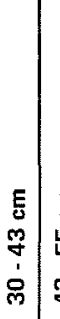 & $\begin{array}{c}E \\
5 \\
5 \\
5 \\
\dot{b} \\
\dot{q}\end{array}$ & $\begin{array}{c}E \\
E \\
\mathscr{0} \\
0 \\
\dot{1} \\
10\end{array}$ & 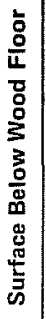 & 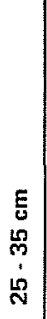 & 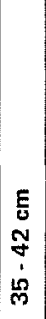 & \begin{tabular}{|c|}
$E$ \\
$E$ \\
$\dot{L}$ \\
$\dot{D}$ \\
$\dot{y}$ \\
\end{tabular} & $\begin{array}{l}E \\
5 \\
\stackrel{5}{\circ} \\
\dot{0} \\
\dot{\circ}\end{array}$ & \begin{tabular}{|l|}
$E$ \\
$E$ \\
0 \\
0 \\
0 \\
1 \\
0 \\
\end{tabular} & $\mid \begin{array}{c}E \\
\overline{0} \\
\bar{T} \\
\dot{0} \\
\dot{0}\end{array}$ & 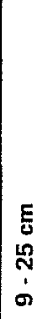 & $\begin{array}{c}E \\
0 \\
N \\
\text { d } \\
\dot{n} \\
\text { N }\end{array}$ & \begin{tabular}{c}
$\varepsilon$ \\
$\tilde{c}$ \\
\multirow{F}{*}{} \\
$\dot{\mathrm{N}}$ \\
ले
\end{tabular} & $\begin{array}{c}E \\
E \\
\frac{E}{5} \\
\\
0\end{array}$ & $\begin{array}{l}E \\
\text { U } \\
\stackrel{2}{2} \\
\dot{2} \\
=\end{array}$ & $\begin{array}{l}\frac{\varepsilon}{0} \\
\bar{m} \\
\dot{\sigma} \\
\sigma\end{array}$ & $\left|\begin{array}{c}E \\
5 \\
\infty \\
m \\
1 \\
\bar{m}\end{array}\right|$ & $\mid \begin{array}{c}E \\
0 \\
0 \\
\frac{5}{2} \\
\dot{0}\end{array}$ & $\begin{array}{l}E \\
E \\
N \\
N \\
1 \\
n \\
\sim\end{array}$ & $\mid \begin{array}{c}E \\
\overline{0} \\
\mathcal{N} \\
\mathfrak{N} \\
\hat{N}\end{array}$ & \\
\hline \multirow{13}{*}{ 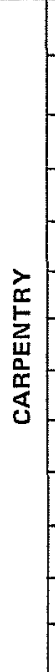 } & Square Nails & 2 & 2 & 7 & 4 & 1 & 3 & & 3 & 1 & 6 & 1 & & 21 & 42 & 6 & & 18 & 17) 5 & 52 & 20 & 6 & & 14 & 2 & 1 & 1 & 2 & & 3 & 8 & 8 & 2 & 1 & 2 & & 1 & 4 & 2 & 263 \\
\hline & Wire Nails & & 1 & 2 & & 6 & & & 4 & & 4 & & & 16 & 7 & & & 235 & $58 \quad 2$ & 24 & & & & 3 & & & & & & 2 & 4 & 2 & 5 & 2 & 2 & & & 7 & 1 & 173 \\
\hline & Staples & & & & 1 & & & & & & & & & & & & & 3 & 1 & & & & & 1 & & & & & & & & & & & & & & & & 6 \\
\hline & Railroad Spike & & & & 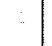 & & & & & & & & & 1 & & & & & & & & & & & & & & & & & & & & & & & & & & 1 \\
\hline & Roofing Nails & & & & & & & & & & & & & & & 2 & & 2 & 2 & & & & & & & & & & & & 1 & & & & & & & & & 7 \\
\hline & Tacks & & & & & & & & & & & & & & 5 & & & 1 & & 1 & & & & & & & & & & & & & & & & & & & & 7 \\
\hline & Wood Screws & & & 2 & & & & & & & & & & & & & & & & 1 & & & & & & & & & & & & & & & & & & & & 3 \\
\hline & Nuts & & & & & & & & & & & & & & & & & & & 2 & & 1 & & & & & & & & & & & & & & & & & & 3 \\
\hline & Washers & & & & & & & & & & & & & & & & & & 1 & & & & & & & & & & & & & & 1 & & & & & & & 2 \\
\hline & Wood Flooring Fragments & & 2 & & & & & & & & & & & & & & & & & & & & & & & & & & & & & & & & & & & & & 2 \\
\hline & Miscellaneous Wood Fragments & 4 & 4 & 10 & 3 & & & & 12 & & & & & & & & & & & & & & 1 & 6 & & & & & & & & 1 & 1 & 1 & & & & & & 43 \\
\hline & Linoleum Fragments & & & & & & & & & & & & & 2 & & & & 10 & & & & & & & & & & & & & & & & & & & & & & 12 \\
\hline & Window Pane Fragments & 2 & 4 & 3 & 9 & 2 & 1 & & 6 & & 1 & 2 & & 39 & 18 & 11 & & 222 & $22] 1$ & $15:$ & 5 & 2 & 2 & 11 & 1 & 1 & & & & & 4 & 22 & 2 & 1 & & & & & 1 & 209 \\
\hline \multirow{3}{*}{ 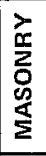 } & Brick Fragments & & $x$ & $x$ & & & & & $x$ & $x$ & & & & $x$ & & $x$ & & $\mathrm{x}$ & $x$ & $x$ & & & & $x$ & & & & & & & $x$ & & & & & & $\mathrm{x}$ & & & \\
\hline & Plaster Fragments & $x$ & $x$ & $x$ & $x$ & & & & $x$ & & & & & & & & & $x$ & $x$ & & & & & & $x$ & $x$ & & & & & & $x$ & & & & & & & & \\
\hline & Concrete \&/or Mortar Frags. & & & $x$ & & & & $x$ & & & & & & & & & & & & & & & & & & & & & & & & & & & & & & & & \\
\hline \multirow{3}{*}{ 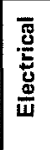 } & Wire & & & & & & & & & & & & & & & & & & & & & & 1 & 1 & & & & & & & & & & & & & & & & 2 \\
\hline & Porcelain Insulator Fragments & & & & & & & & & & & & & & 3 & & & & & & & & & & & & & & & & & & & & & & & & & 3 \\
\hline & Slugs & & & & & & & & & & & & & 1 & & & & & 1 & & & & & 1 & & & & & & & & & & & & & & & & 3 \\
\hline \multirow{4}{*}{ 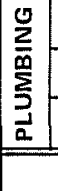 } & Faucet Handle & & & & & & & & & & & & & & & & & 1 & & & & & & & & & & & & & & & & & & & & & & 1 \\
\hline & Lead Splash & & 1 & & & & & & & & & & & & & & & 1 & & & & & & & & & & & & & & & & & & & & & & 2 \\
\hline & Sewer Pipe Fragments & & & & & & & & & & & & & & & & & & & & & & & & & & & & & & 1 & 5 & & & & & & & & 6 \\
\hline & TOTALS & 8 & 14 & 24 & 17 & 9 & 4 & 0 & 25 & 1 & 11 & 3 & 0 & 80 & 75 & 19 & 0 & \begin{tabular}{|l|l|l}
81 & 10 \\
\end{tabular} & 102.9 & \begin{tabular}{l|l}
95 & 2 \\
\end{tabular} & 25 & 9 & 4 & 37 & 3 & 2 & 1 & 2 & 0 & 5 & 18 & 38 & 11 & 5 & 4 & 0 & 1 & 11 & 4 & 748 \\
\hline
\end{tabular}

NOTE: For TP No. 1-3, elevation is below surface of wood floor in stone building. For TP No. 4-6, elevation is below surface of wood floor in Palisado House.

For Shovel Test No. 1 and 2, elevation is below ground surface (approximately $8 \mathrm{~cm}$ below surface of wood floor in stone building). 


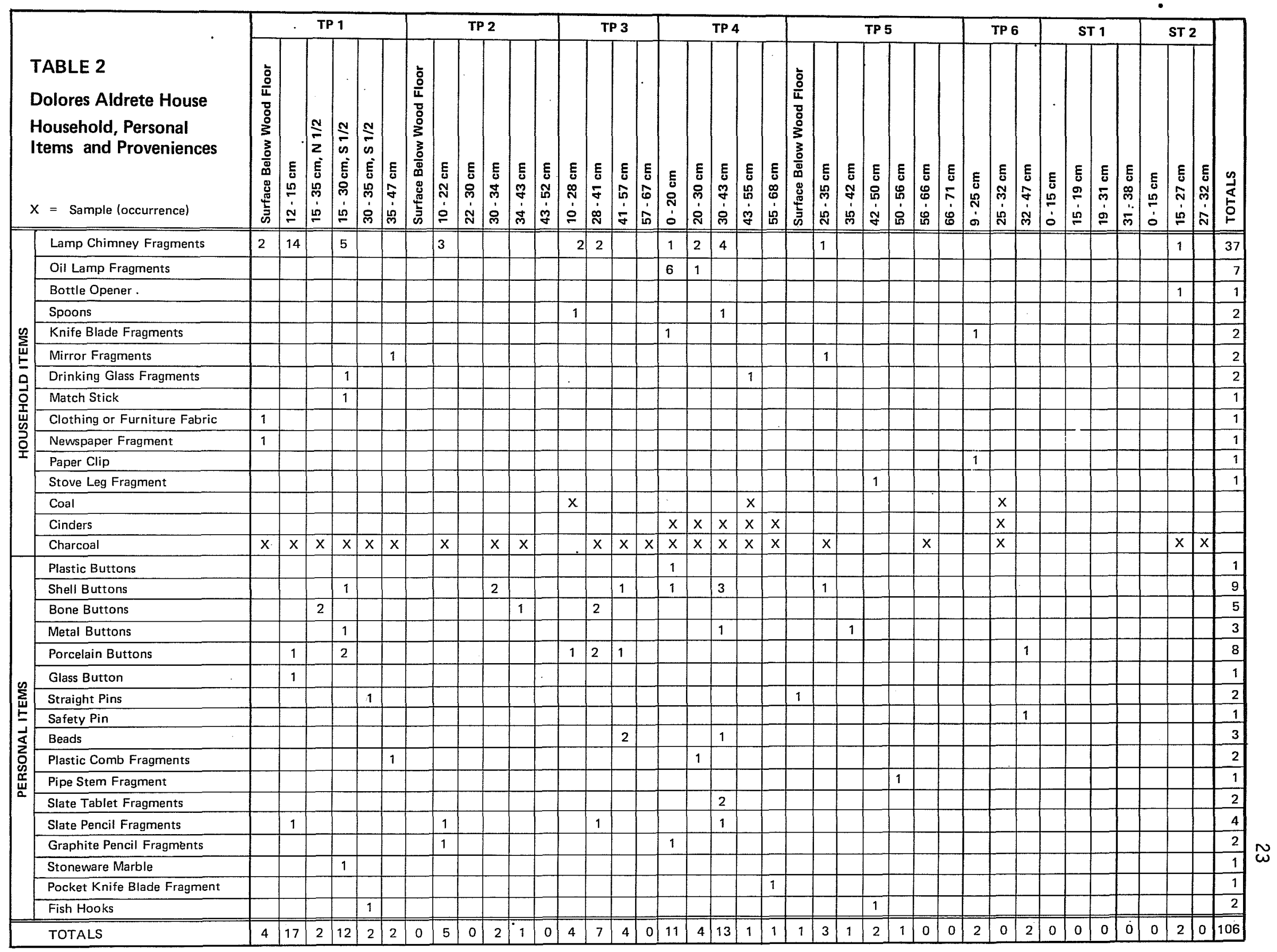




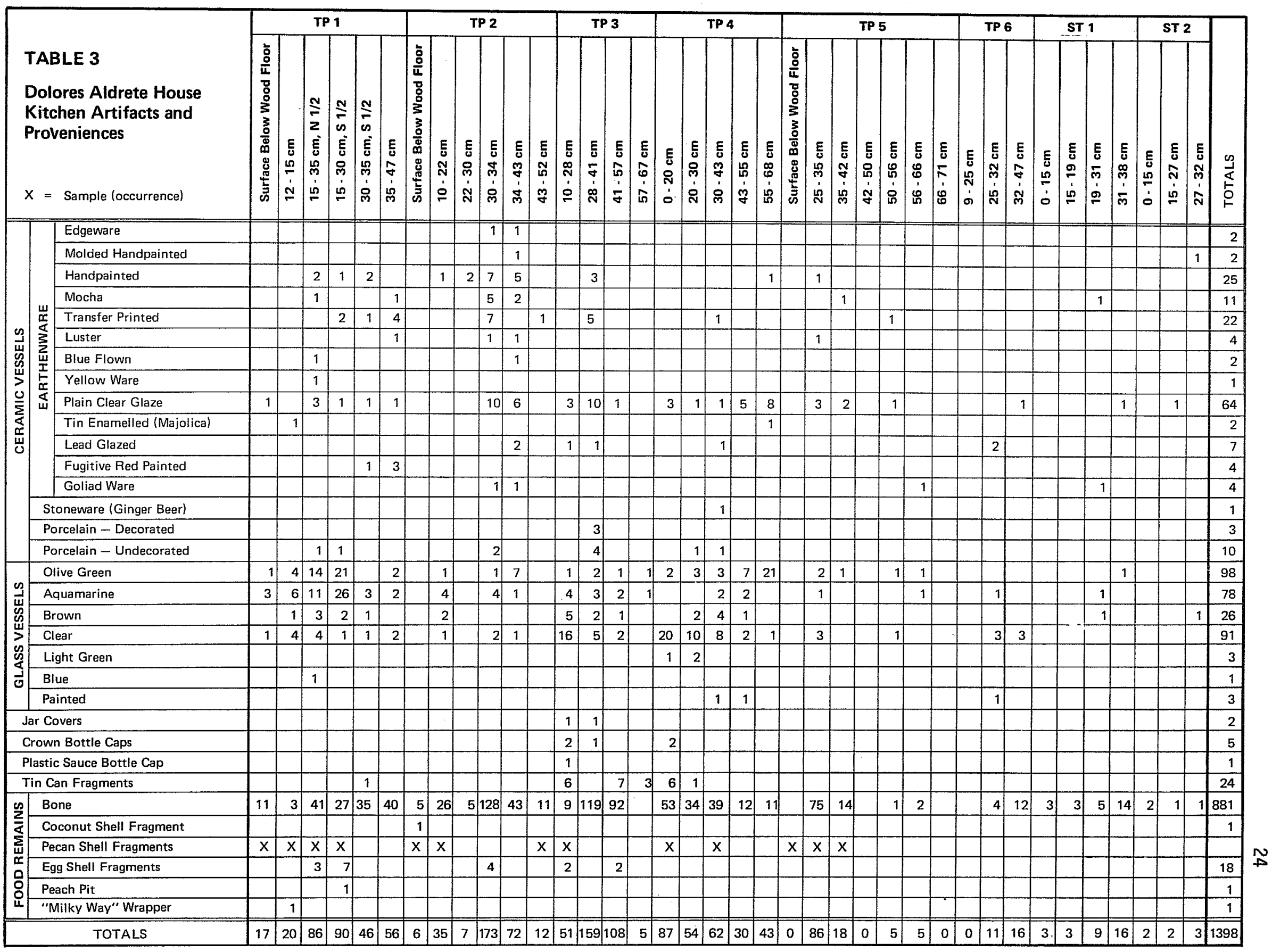




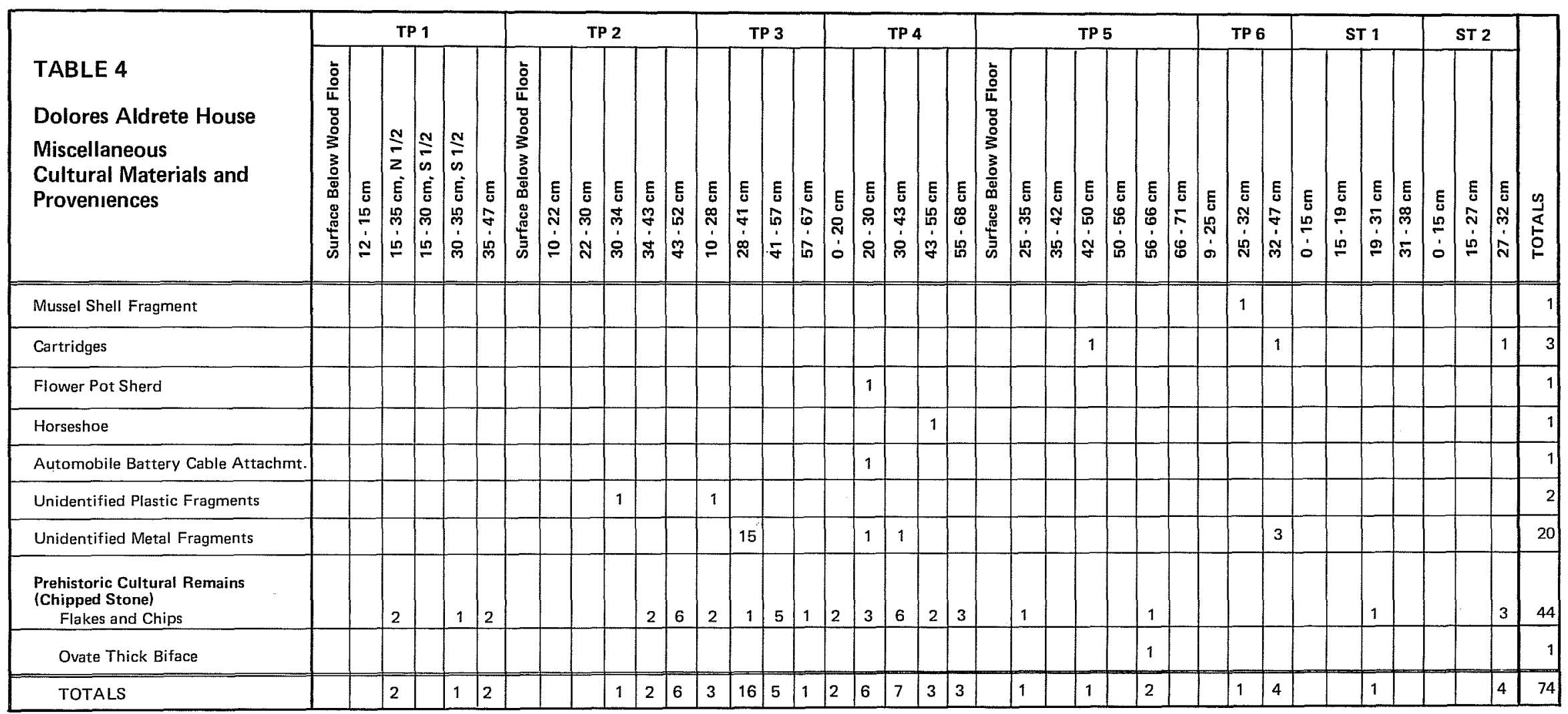


Clothing fasteners, beads, comb fragments, pencils, fish hooks and other personal items (Fig. 10,g-p) probably were lost or discarded by the site's many occupants and visitors. The relatively small proportion of firearm-related materials and artifacts related to machinery, agriculture and transportation reflects the urban residential nature of the 19th and early 20th century occupation. Pieces of chipped stone are evidence of prehistoric and possibly early historic occupation of the general site area.

\section{INTERPRETATIONS AND CONCLUSIONS}

As an archaeological resource, the Dolores Aldrete House property is relatively well preserved. Although altered extensively by structural addition, renovation and maintenance, the early 19th century palisado house and the mid-19th century Caile House contain significant architectural and archaeological information. The cultural fill beneath the wooden floors of these structures and the fill zones outside on lot 9 average approximately $33 \mathrm{~cm}$ in depth and contain cultural material representative of the site's function and chronology of occupation. The soils beneath the gravel parking area and the 20th century structures on lots 7 and 8 were not excavated; however, it is possible that these deposits also contain cultural material and structural remains.

The chronology of occupation of the property is reflected in the distribution of cultural material within the fill that covers the site. Most of the artifact sample can be associated generally with the 19th and 20th centuries. Table 5 associates selected artifact types with time spans during which they are known to have been produced and used. Table 6 associates these chronological periods with fill zones penetrated by test excavations. Table 7 presents a summary of the chronology of events at the site, based on archaeological and historical information. More specific dates for events cannot be determined from archaeological evidence because: (1) animal and construction disturbances have contaminated some older deposits with more recent cultural material, and (2) there is limited scientific knowledge of the types of cultural material associated with the first quarter of the 19th century.

A change in the function of the Dolores Aldrete House property may be reflected by the material culture sample. Most of the artifacts appear to be representative of building construction and residential household occupations during the 19th and early 20th centuries. The lack of ceramics and other household garbage of the mid-20th century (for example., decal ware and Texas-made stoneware) may represent a change to commercial use of the site during the 20th century . It also is possible that the advent of public garbage collection could account for this negative evidence, although this does not seem likely. Such research problems must be considered during future archaeological investigations at historic sites in the downtown San Antonio area.

\section{RECOMMENDATIONS}

Preliminary archaeological investigations of the Dolores Aldrete House property resulted in the accumulation of archaeological and historical information which can be used in the management of the site as a cultural resource. Planning of future construction work at the site should consider the following recommendations: 
TABLE 5. DOLORES ALDRETE HOUSE. CHRONOLOGICAL ASSOCIATION OF SELECTED ARTIFACT CATEGORIES.

Artifact Category

Approx. Time Span

References

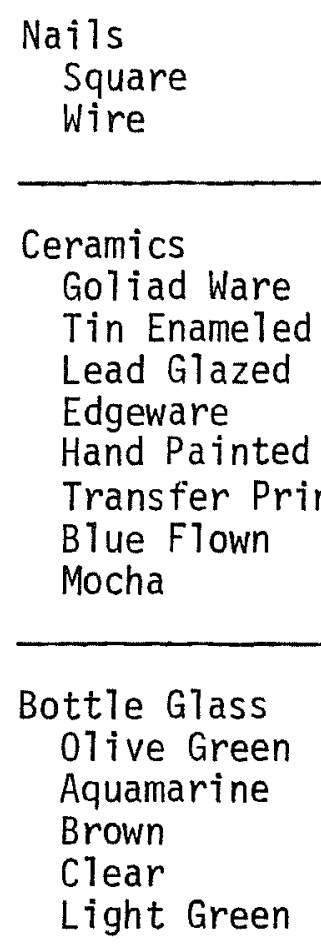

19 th century

20 th century

18th century

18th-19th cent. 18th-19th cent. early \& mid 19th early \& mid 19th early \& mid 19th early \& mid 79th early \& mid 19th
Davis and Corbin 1967; Fox 1970;

Fox, Bass and Hester 1976;

Greer 1967; McClinton 1951; Schuetz 1969; and others primarily mid \& late 19th primarily mid \& late 19th late 19th \& 20th primarily 20th primarily 20 th
Scurlock and Fox 1977:77-87. 
TABLE 6

DOLORES ALDRETE HOUSE

Chronological Association of Cultural Deposits

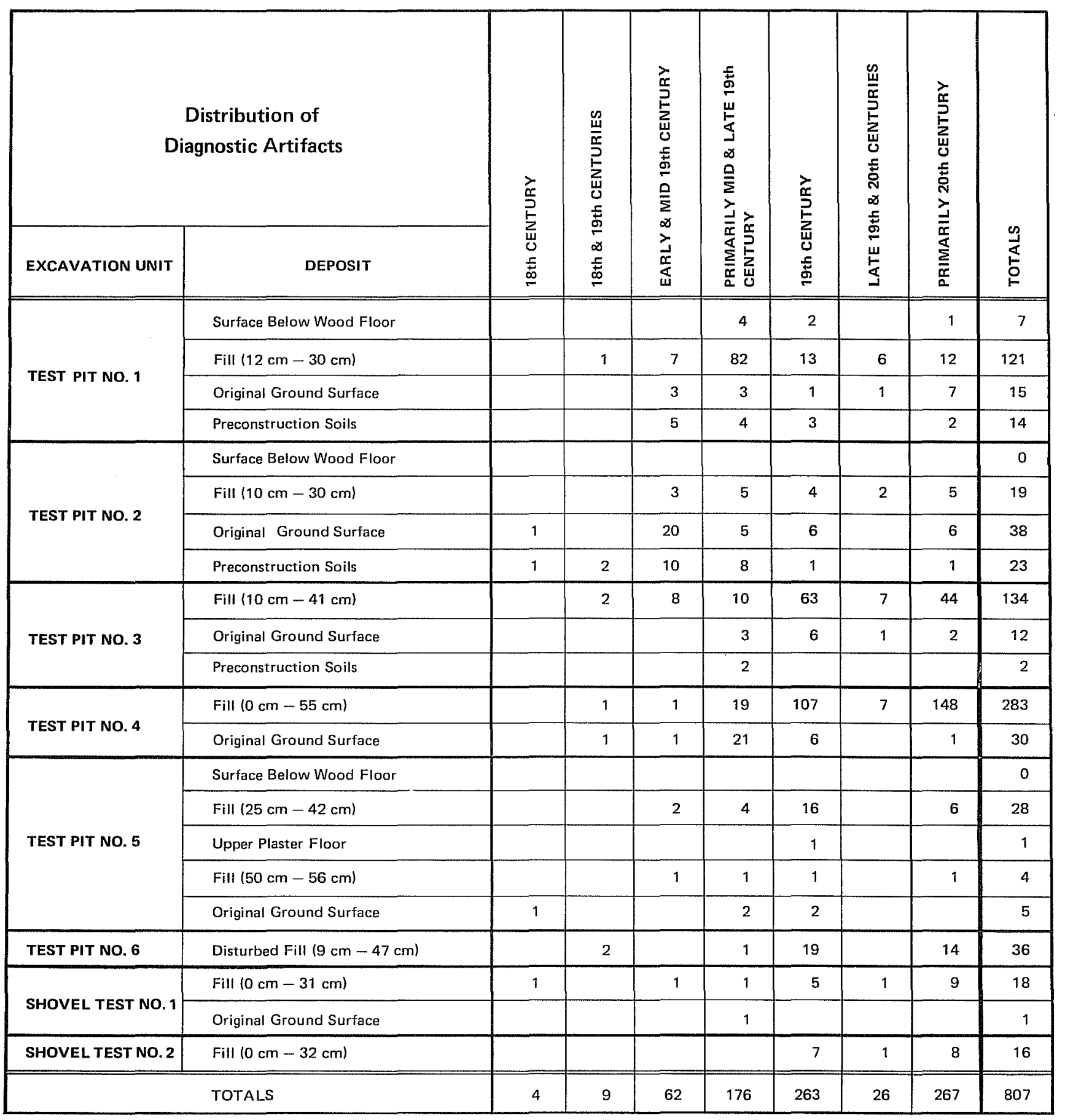


TABLE 7. DOLORES ALDRETE HOUSE. CHRONOLOGY OF EVENTS.

\begin{tabular}{|c|c|c|}
\hline Time Span & Event & $\begin{array}{l}\text { Basis for } \\
\text { Interpretation }\end{array}$ \\
\hline Prehistoric & $\begin{array}{l}\text { Aboriginal occupation of } \\
\text { the general site area }\end{array}$ & Chipped Stone \\
\hline 18th Century & $\begin{array}{l}\text { Possible occupation of the } \\
\text { general site area by Spanish } \\
\text { Colonial peoples }\end{array}$ & $\begin{array}{l}\text { Goliad Ware (Mission } \\
\text { pottery), tin enameled } \\
\text { earthenware; historic } \\
\text { accounts }\end{array}$ \\
\hline $1812-1840 \mathrm{~s}$ & $\begin{array}{l}\text { Construction and initial } \\
\text { residential occupation of } \\
\text { the palisado house (lot 9) }\end{array}$ & $\begin{array}{l}\text { Early and mid-19th } \\
\text { century ceramics, } \\
\text { minimal representation } \\
\text { of possible } 18 \text { th cent- } \\
\text { ury material culture; } \\
\text { historic records } \\
\end{array}$ \\
\hline $1850 \mathrm{~s}$ & $\begin{array}{l}\text { Construction of the Caile } \\
\text { House (lots } 7 \text { and } 8 \text { ) }\end{array}$ & $\begin{array}{l}\text { 19th century cultural } \\
\text { materials in preconstruc } \\
\text { tion soils; historic } \\
\text { records }\end{array}$ \\
\hline $1850 s-1890 s$ & $\begin{array}{l}\text { Residential occupation and } \\
\text { maintenance of both struc- } \\
\text { ures (lots } 7,8 \text { and } 9 \text { ) }\end{array}$ & $\begin{array}{l}\text { 19th century household } \\
\text { garbage and construc- } \\
\text { tion debris }\end{array}$ \\
\hline $1880 \mathrm{~s}-1920 \mathrm{~s}$ & $\begin{array}{l}\text { Wood additions to the } \\
\text { palisado house (lot } 9 \text { ) and } \\
\text { construction of brick and } \\
\text { frame addition to rear of } \\
\text { the Caile House (lots } 7 \text { and } \\
\text { 8) }\end{array}$ & $\begin{array}{l}\text { Upper plaster floor in } \\
\text { palisado house; concrete } \\
\text { footing for addition to } \\
\text { Caile House; historic } \\
\text { records }\end{array}$ \\
\hline $1920 \mathrm{~s}$ & $\begin{array}{l}\text { Destruction of the north } \\
\text { wall and construction of a } \\
\text { brick facade on the Caile } \\
\text { House (lots } 7 \text { and } 8 \text { ), and a } \\
\text { change from residential to } \\
\text { commercial occupation (lots } \\
7,8 \text { and 9) }\end{array}$ & $\begin{array}{l}\text { Recent construction } \\
\text { debris; minimal repre- } \\
\text { sentation of mid-20th } \\
\text { century household gar- } \\
\text { bage; historic records }\end{array}$ \\
\hline 1930s-present & $\begin{array}{l}\text { Structural alterations and } \\
\text { renovations to the Caile } \\
\text { and palisado houses, con- } \\
\text { struction of } 20 \text { th century } \\
\text { structures east of the } \\
\text { palisado house (lots } 7 \\
\text { and } 8 \text { ) }\end{array}$ & $\begin{array}{l}\text { Extant structures; } \\
\text { historic records; ora1 } \\
\text { history }\end{array}$ \\
\hline
\end{tabular}


1. Although lot 9, on which the palisado house stands, appears to be the best preserved of the three adjacent lots that make up the property, it is possible that significant archaeological deposits are buried beneath the gravel parking area and the 20th century structures on lots 7 and 8 . Earthmoving activities in these areas should be monitored by a trained archaeologist.

2. Cultural deposits beneath the palisado house (lot 9) and the Caile House (lots 7 and 8) are well preserved, contain important archaeological and architectural evidence, and should be avoided as much as possible by future renovation or construction activities.

3. The palisado house and the Caile House can be considered artifacts, in themselves, fashioned by the 19th and 20th century inhabitants of downtown San Antonio. The numerous late 19th century and 20th century additions to the two 19th century structures are representative of the cultural heritage of the La Villita neighborhood. Alteration or renovation of above-ground structural features should be supervised by an architectural specialist.

4. Much can be done with the archaeological information presented in the preceding report and with the collections of cultural material recovered during the investigation. The data should be made available for comparative study during future archaeological work in downtown San Antonio. 


\section{REFERENCES CITED}

Chabot, F. C.

1937 With the Makers of San Antonio. Artes graficas, San Antonio.

Davis, E. and J. E. Corbin

1967 Archeological Investigations at Washington-on-the-Brazos State Park. State Building Commission Archeological Program 5.

Eaton, J. D.

n.d.a Archaeological Excavations at the Alamo Shrine (Mission San Antonio de Valero), San Antonio, Texas. Center for Archaeological Research, The University of Texas at San Antonio. Manuscript in preparation.

n.d.b Excavations at San Fernando Cathedral, San Antonio, Texas. Center for Archaeological Research. The University of Texas at San Antonio. Manuscript in preparation.

Fox, A. A.

1977 The Archaeology and History of the Spanish Governor's Palace Park. Center for Archaeological Research, The University of Texas at San Antonio, Archaeological Survey Report 31.

Fox, A. A., F. Bass, Jr. and T. R. Hester

1976 The Archaeology and History of Alamo Plaza. Center for Archaeological Research, The University of Texas at San Antonio, Archaeological Survey Repont 16.

Fox, D. E.

1970 Archeological Salvage at Mission San Jose, December 1969, April and August 1970. Texas Historical Survey Committee, Office of the State Archeologist Special Report 3.

Fox, D. E., D. Scurlock and J. W. Clark, Jr.

1977 Archeological Investigations at San Fernando Cathedra7: A Preliminary Report. Office of the State Archeologist Special Report 22.

Greer, J. W.

1967 A Description of the Stratigraphy, Features and Artifacts from an Archeological Excavation at the Alamo. State Building Commission Archeological Program Report 3. 
Ivey, J. E.

1978 Archaeological Investigations at the Gresser House, 41 BX 369, San Antonio, Texas. Center for Archaeological Research. The. University of Texas at San Antonio, Archaeological Survey Report 60.

McClinton, K. M.

1951 Antique Collecting for Everyone. Crown Publishers (Bonanza Books), New York.

Rams de11, C.

1959 San Antonio, A Historical and Pictorial Guide. The University of Texas Press, Austin. Revised edition by Carmen Perry, 1976.

Santos, R. G.

1965 El Quartel, Spanish Fortification Built in San Antonio de Bexar in 1810. (Available in office of San Antonio Conservation Society.)

Schuetz, M. K.

1969 Description of the Artifacts and Ethno-History of the Coahuiltecan Indians. The History and Archeology of Mission San Juan Capistrano, San Antonio, Texas II. State Building Commission Archeological Program Repart 11.

1970 Excavation of a Section of the Acequia Madre in Bexar County, Texas, and Archeological Investigations at Mission San Jose in Apri1 1968. Texas Historical Survey Committee Archeological Report 19.

n.d. Cuartel Investigations. Manuscript on file at Texas Historical Commission.

Scurlock, D. and D. E. Fox

1977 An Archeological Investigation of Mission Concepcion, San Antonio, Texas. Texas Historical Commission, Office of the State Archeologist Report 28.

Tunnel1, C.

1966 A Description of Enameled Earthenware from an Archeological Excavation at Mission San Antonio de Valero (the Alamo). State Building Commission Archeological Program Report 2. 